FOSSIL VERTEBRATES IN THE CDCA 


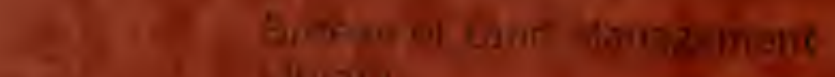

Ly-y

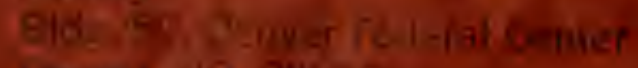

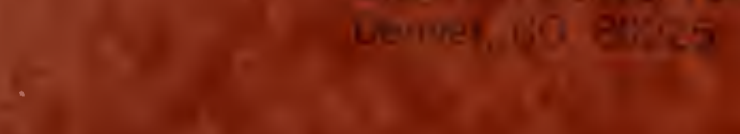

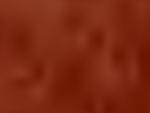




\section{FOSSIL VERTEBRATES IN THE CDCA}

1978

by

\section{0. Woodburne \\ 785 Spruce St. \\ Riverside, CA.}

Purenus of lantil illanagament

Libi $r y$

E 74 50. Denus. Federal Center

U ive., CU Con25

for

Bureau of Land Management

1695 Spruce Street

Riverside, Califormia 92507

Contract CA-060-CT7-2814 
Fossil vertebrates in the CDCA

CE
841

- $\$ 66$

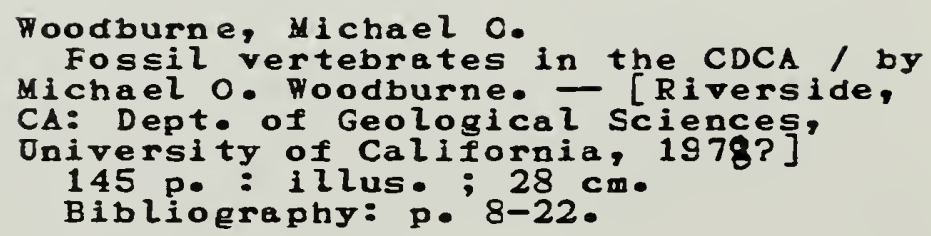

1. Vertebrates, Fossil--California Cesert. 2. Faleontology-Calíforaia Desert. 3. California Desert Conservation Area--paleontology. I. Title 


\section{Table of Contents}

Introduction and Summary

Section A. List of published works, theses, unpublished reports, government and private, containing significant data on fossil vertebrates in the CDCA.

Section B. Location maps for fossil sites in the CDCA, and comments on probability of occurrence, age designations.

Section C. Narrative, keyed to Maps 1 and 2, with respect to areas of known or high potential for the occurrence of fossil vertebrates in the CDCA, and a list for each area of institutions with major collections, references to bibliography, and classification with regard to their value for research, educational, recreational, and industrial potential.

Section D. Brief narrative, keyed to Maps 1 and 2, with respect to areas of lower potential for fossil vertebrates.

Section E. Classification of sites as to their research, educational, recreational, and industrial potential. This is part of Section $C$.

Section F. Discussion of impacts of natural and human activities on fossil vertebrate sites in the CDCA.

Section G. List of institutions which have significant collections of vertebrate fossils from the CDCA, including names and addresses of curators.

Section H. List of names and addresses of specialists with interest in the CDCA vertebrate fossils. 
Table of Contents (continued)

Section I. Cross index for maps, text, institutions with collections, and bibliography. This is part of Section C.

Section J. Value, occurrence, recovery, preservation, and collection of vertebrate fossils. 
Note

The colors on the maps are water-soluble. If necessary they can be sprayed with Krylon Workable Fixative, which will keep the colors intact, and will take ink when dry. 


\section{Introduction and Summary.--This report surveys known and potential} fossil vertebrate sites in the CDCA. Forty-nine areas of known occurrence or high potential have been identified (Maps 1 and 2 , and Section $C$ ). Areas of lower potential are also shown on the maps, and briefly discussed in Section D.

The report focuses on information pertinent to aid the Bureau of Land Management in its task of appraising the needs, and interests, sometimes conflicting, of various individuals, groups, institutions, and the like. The arrangement of the sections (see Table of Contents) is sufficient to that end, but in order to appreciate the nature of the problem, Section $J$ probably should be read first.

The following overview and summary of recornmendations is based on the material discussed in the various sections.

Overview.--Basically, fossil vertebrates are a nonrenewable resource, of considerable interest and value to the general public as well as to members of the scientific community. Over the years, the study of fossil vertebrates has become increasingly refined, so that previous practices - wherein a collector went out and made a collection with a low degree of sophistication as to collecting and data recording techniques - are no longer sufficient to the job.

In short, in order to collect fossil vertebrates in a way that makes them meaningful to their maximum potential, one needs professional-level training and facilities, even if the individual doing the job is not labelled as a "professional." He needs to know not only how to physically collect the specimens in the best way, but also how to record the relevant data (and 
what they are), how to use the maps and aerial photographs (and how to get them ahead of time), etc. Certainly, nonprofessionals find fossils, and some reach the attention of individuals who can assess and appreciate the significance of what has been found, and follow it up. But this usually is a random process, whereas the professional - or one with similar capabilities most often has the necessary background, motivation, and interest to do the job correctly, and to inspect an area in a systematic way.

In a nutshell, fossil vertebrates in the CDCA are relatively rare. As shown by the relatively slim bibliography in Section $A$, there is only a small volume of published information on these fossils. As indicated in the Research and Educational assessments in Section $C$, these rare fossils are important, and in effect give the only meaningful information on the land life of the CDCA during the past 60 million.years. The normal effects of both natural and human activities is negative; that is, the fossils are destroyed, and once destroyed the resource is nonrenewable. Maps 1 and 2 try to show where fossil vertebrates do occur, and whereas it is possible to estimate this based on experience, lithologic associations, etc., it is impossible to state ahead of time that fossils will not occur in an area of sedimentary rock. This can be ascertained only after a thorough search. Based on the above considerations and discussions in the text, the following recommendations are presented.

Recommendations.--1. No area of sedimentary rock, with the possible exception of one covered with Recent alluvium, should be written off without making a thorough search for fossil vertebrates. The above possible exception is voided as soon as trenching or excavations are contemplated. At the least, trench or excavation sites should be kept under surveillance during the operations by someone who knows what the fossils are. 
All projects should include funding for on-site investigations for fossil values. For areas shown in blue on Maps 1 and 2, a study of some duration prior to impact should be funded, by the individual, company, etc., causing the impact of the site. The amount of man-hours required for this study and removal of fossils should be determined by consultation with an appropriate specialist (see Section $H$ for a list; in most cases the geographically nearest specialist will be the best. If needed, he can call in others.)

A11 areas colored brown must be funded for initial appraisal, and subsequent removal of fossils synchronous with impact work must be allowed for. For areas colored yellow, investigations synchronous with the impact work must be allowed and funded by whoever is impacting the site.

Finally, the color value of any brown or yellow area can become blue, depending on what fossil values are uncovered.

Mitigation of impact is straightforward and usually does not unduly delay the project, if a qualified professional undertakes or supervises survey or salvage kork, as described in sections $J$ and $F$. 
2. Once fossil vertebrates are found, they should be brought to the attention of one of the individuals listed in Section $H$.

3. Conservation and preservation of fossil vertebrates should be taken to mean salvage and collection of the fossil by qualified professionals, their proper cleaning, curating, and storage or exhibition in qualified instructional or educational institutions. Fossils cannot be preserved by leaving them "in the rock, at the site." They will be destroyed by natural or human activities. The only exception to this is if a permanent shelter is built over the site, and kept under surveillance, or otherwise made secure on a 24-hour basis.

4. Survey and salvage work for fossil vertebrates by professionals, or under professional supervision should be encouraged wherever possible. Antiquities Act permits for this purpose should be granted to cover large areas.

5. Authority to grant permission to make professional salvage and survey of areas in the CDCA should be transferred from the lashington to the District offices of the BLM. Liason between the BLM and individuals and institutions listed in Section $G$ and $H$ should be encouraged and maintained.

6. Statements in the geological anthropological, or even paletontological literature that "no fossils were found" should not be taken as evidence of nonoccurrence. Any area of sedimentary rock that comes under is likely to be affected by human activity should be newiy prospected for fossils before that activity is begun. Oniy then will a "no fossils were found" statement be meaningful, and even then some might have been overlooked.

7. Fossil vertebrates should not be treated as commercial items. Their sale should be discouraged. Sale of fossils collected from areas covered by Antiquities Act statutes is illegal. 


\section{$\underline{B} \underline{I} \underline{B} \underline{L} \underline{I} \underline{O} \underline{G} \underline{R} \underline{A} \underline{P} \underline{H} \underline{Y}$ - Publ ished Reports}

P-1. Alf, R.M., 1966, Mammal Trackway from the Barstow Formation, Calif., Bul1. S. Calif. Acad. Sci. 65: 253-264.

* P-2. Axelrod, D.I., 1940, A Record of Lyonothamnus in Death Valley, Calif., Jour. Geol. 48: 526-531.

* P-3. Bowden, A.0. and Lopatin, I.A., 1941, Fossil Man in Southern Calif., Bul1. G.S.A. 52:1995 (abs).

P-4. Buwalda, John P., 1914, Pleistocene Beds at Manix in the Eastern Mohave Desert Region, U.C. Press Bul1. 7:443-464.

P-5. Buwalda, J.P. and Lewis, G.E., A New Species of Merychippus, U.S.G.S. Prof. Pap. 264-G: 147-152.

*P-6. Crabtree, D.E., 1939, Mastodon Bone with Artifacts in California, American Antiq. 5:148.

*P-7. DesLauriers, J.R., 1965, A New Miocene Tortoise from Southern California, Bul1. S. Calif. Acad. Sci. 64:1-10.

P-8. Downs, T., 1965, Pleistocene Vertebrates of the Colorado Desert, Calif., 7th Internat. Congr. Inter. Ass. Quat. Res. abs. 1965:107.

.P-9. , 1968, Fossil Vertebrates of Southern California, Calif., Nat. Hist. Guides 23: 61pp.

P-10. , Hovards, H., Clements, T., and Smith, G.A., 1959, Quaternary Animals from Schuiling in the Mojave Desert, Calif., Contrib. Sci.: L.A.C.M. no. 29, 21 pp.

P-11. , and White, J.A., 1965, Late Cenozoic Vertebrates of the AnzaBorrego Desert Area, Southern Calif., Program, Sect. E (Geol, Geog) Amer. Assoc. Advanc. Sci. Meeting 1965: 10-11 (abs).

P-12. 1968, A Vertebrate Faunal Succession in Superposed Sediments from Late Pliocene to Middle Pleistocene in Calif., 23rd Int. Geol. Congr. Proc., 10: 41-47.

*P-13. Frick, Childs, 1926, The Hemicyoninae and an American Tertizry Bear, AMNH Bul1., vol 56, art 1, 119pp.

$\star P-14$. , 1933, New Remains of Trilophodont - Tetrabelodont Mastadons, AMNH Bu11., vol 59, art 9: 505-652.

*P-15. Giles, E., 1960, Multivariate Analysis of Pleistocene and Recent Coyotes (Canis latrans) from Calif., U.C. Pubs. Geol. Sci. 36: $369-390$.

*P-16. Ginsburg, Leonard, 1955, De 1a Subdivsion du Genre Hemicyon Lortet (Cornassier du Miocene), Bu11. Soc. Geol. France, 5, Sec, 6, 85-99.

$\star=$ references of general interest, not specifically tied to a particular locality. 
P-17. Henshaw, P.C., 1939, A Tertiary Manmalian Fauna from the Avawatz Mountains, San Bernardino County, Calif., Publ. Carnegie Inst. Wash, 5:4, 1-30p.

P-18. Howard, H., 1944, Miscellaneous Avian Fossil Records from California, Bul7. S. Calif. Acad. Sci. 43: 73-76.

P-19. 1955, Fossil Birds from Maniz Lake, Calif., U.S.G.S. Prof. Pap. 264-J: 199-205.

P-20. 1957, A New Species of Passerine Bird from the Miocene of Calif., Contrib. Sci., L.A.C.M., no. 9, $16 \mathrm{pp}$.

P-21. 1963, Fossil Birds from the Anza-Borrego Desert, Contrib. Sci., L.A.C.M., no. 73, 33pp.

*P-22. Jakway, G.E. and Clement, J.T., 1967, An.Endocranial Cast of the Miocene Dog Tomarctus, from the Fossil Beds of Barstow, Calif., Bull.

S. Calif. Acad. Sci., 66: 39-45.

P-23. Jefferson, G.T., 1971, New Pleistocene Vertebrate Sites on the Mojave Desert: a Reconaissance Report, G.S.A. (abs), 3:2, 140-141.

P-.24. Lewis, G.E., 1960, Miocene Vertebrates of the Mojave Desert, Bul1. G.S.A., 71,1916 (abs).

$p-25$. , 1964, Miocene Vertebrates of the Barstow Formation in Southern California, U.S.G.S. Prof. Pap. 475-D: 18-23.

$P-. .6$. -1968, Stratigraphic Paleontology of the Barstow Formation in the Alvord Mountain Area, San Bernardino County, Calif., U.S.G.S. Prof. Pap. 600-C: 75-79.

P-27. Lindsay, E., 1966, Small Mammals in the Upper Barstow Formation, Mojave Desert, Program, 62nd Ann. Meeting G.S.A. Cordilleran Sect., 1966 50-51 (abs).

$\mathrm{P}-28$. , 1967, Cricetid Rodents from the Barstow Syncline, Mojave Desert, Calif., Program, 63rd Ann. Meeting G.S.A. Cordillieran Sect., 46-47 (abs).

P-29. - 1972, Sma 17 Mammalian Fossils from the Barstow Formation, Calif., U.C. Pub. Geol. Sci. 93, 104pp.

*P-30. Logan, T.M., 1873, On the Remains of Fossil Elephants and Mastadons in Calif., Proc. Agassiz Inst., 1872, 73-74.

P-31. McKenna, M.C., 1955, Paleocene Mammal, Goler Formation, Mojave Desert, Calif., Bul1. A.A.P.G. 39: 512-515.

P-32. , 1960, A Continental Paicocene Vertebrate Fauna from -California, A.M.N.H. Novitate no. 2024, 20pp. 
* P-33. Maxson, J.H., 1963, Death Valley Origin and Scenery, 1st Ed., Death Valley Nat. Hist. Assoc. in cooperation with Nat. Park Serv., 59pp.

* P-34. Merkel, D.F., 1966, 1967, The Roadrunner - a Feathered Character, Santa Barbara Mus. Nat. Hist., 41: 65-68.

P-35. Merriam, J.C., 1911, A Collection of Mammalian Remains from Tertiary Beds on the Mohave Desert, But1. U.C. Press 6: 167-169.

P-36. 1913, New Protohippine Horses from Tertiary Beds on the Western Border of the Mohave Desert, U.C. Press Bu17. 7:435-441.

P-37. , 1913, A Peculiar Horn or Antler from the Mohave Miocene California, U.C. Press Bu77. 7:335-339.

P-38. , 1915, Extinct Faunas of the Mohave Desert; Their Significance in a Study of the Crigin and Evolution of Life in America, Pop. Sci. Monthly, pp 245-264.

P-39. , 1919, Tertiary Mammalian Faunas of the Mohave Desert, U.C. Pub.:Bu11. Dept. Grol., no. 11:437-585.

P -40 . , and Pack, R.W., 1913, Suggested Paleontological Correlation Between Continental Miocene Deposits of the Mohave Region and Marine Tertiary Beds of San Joaquin Valley, Ca., G.S.A. Bu17. 24: 128 (abs).

P-41. Miller, L.H., 1950, A Míocene Flamingo from California, Condor 52:69-73.

P-42. 1952, The Avifauna of the Barstow Miocene of California, Condor 54: 296-301.

* P-43. Morris, William J., 1965, Graphic Analysis of Some Miocene Horse Astragoli from California, Jour. Paleo. 39:657-662.

P-44. Opdyke, N.D., Lindsay, E.H., Johnson, W.M., et.al., 1977, The Paleomagnetism amd Magnetic Polarity Stratigraphy of the MammalBearing Section of the Anzo-Borrego State Park, California, Quat. Res. (Wash. Univ. Quat. Res. Cent.) vol 7, no 3: 316-329.

* P-45. Osborn, H.F., 1918, Equidae of the 01igocene, Miocene, and Pliocene of North American Iconographic Type Revision, Mem. A.M.N.H., N.S. II, pt. I.

P-46. Pierce, U.D., 1959a, Fossil Arthropods of Calif., No 22 Bull. S. Cal. Acad. Sci. 58: 72-78.

P-47. , 1959b, Silicified Eggs of Vertebrates From Calico Mts. Nodules, Bul1. S. Calif. Acad. Sci. 58: 79-83.

P-48. , 1962, The Significance of the Petroliferous Nodules of Our Desert Mountains, Bul1. S. Calif. Acad. Sci. 61: 7-14. 
P-49. Price, J., 1965, Fossil Beds of the Calicos, Desert Mag. 28:2, pp 10-11.

P-50. Reynolds, R.E. and Jefferson, 1971, Late Pleistocene Vertebrates from Valley Wells, Mojave Desert, Calif., G.S.A. Abst. 3:2, 183 (abs).

P-51. Richey, K.A., 1940, New Evidence on the Faunal Relations of the Ricardo, Mint Canyon, and Barstow Formations, Bull. G.S.A. 51: 1986 (abs).

P-52. 1941, Occurrence of Chinese Felid Genus Metailurus in Pliocene of Calif., Bul1. G.S.A. 52: 1982-1983 (abs).

P-53. Savage, D.E., Downs, T. and Poe, O.J., 1954, Cenozoic Land Life of Southern California, Cal. Div. Mines Bull. 170, Chap 3.

* P-54. Schultz, C.B. and Falkenback, C.H., 1940, Merycochaerinae, a New Subfamily of Oreodonts, A.M.N.H. Bul.1. 77, art 5: 213-306.

* $\mathrm{P}-55$. 1941, Ticholeptinae, a New Subfamily of Oreodonts, A.M.N H. Bu11. 74, art 1, 105pp.

* P-56. Simpson, G.G., 1933, Glossary and Correlation Charts of North American Tertiary Mammal- Bearing Formations, Bull. A.M.N.H., vol 67, art 3: 79-121.

* P-57. Stirton, R.A., 1940, Phylogeny of North American Equidae, U.C. Pub. Bull. Dept. Geol. Sci. 25: 165-198.

P-58. Stock, Chester, 1949, Mammalian Fauna from the Titus Canyon Formation, Calif., in Some Tertiary Mammals and Birds from North America, VIII, Pub. Carnegie Inst. Wash. 584: 229-244.

P-59. Tedford, R.H., 1966, Late Tertiary Mammal Succession, Mojave Desert Region, Southern California, Spec. Pap. G.S.A. 87: 318 (abs).

P-60. and Alf, R.M., 1962, A New Megahippus from the Barstow Formation, San Bernardino County, Calif., BulT. S. Calif. Acad. Sci. 61: 113-122.

P-61. Von Huene, R., 1971, Fossi] Mammals of the Indian Wells Valley Region and How to Collect Them, Maturango Mus., China Lake, Calif., Pub 5, 18pp.

P-62. West, R.M., 1970, Tetraclaenodon puercensis (Mammalia: Phenacodontidae), Goler Formation, Paleocene of Calif., and Distribution of the Genus, Jour. Paleo. 44:5, 851-857.

P-63. White, John A., 1968, A New Porcupine from the Middle Pleistocene of the Anza-Borrego Desert of California, L.A.C.M. Contrib. in Sci., no 136, $15 p p$.

P-64. , and Downs, T., 1961, A New Geomys from Vallecito Creek Pleistocene of California, with Notes on Variation in Recent and Fossil Species, L.A.C.M. Contrib. Sci., no 42, 34pp. 
P-65. Whistler, D.P., 196 , New Hemingfordian (Middle Miocene) Mammalian Fauna from Boron, Calif. and Its Stratigraphic Implications Within the Western Mojave Desert. Spec. Pap. G.S.A. 101: 344-345 (abs).

P66. , 1969, Late Tertiary Lizards and Snakes of the Mojave Desert, G.S.A. Abst., Part 3: 73 (abs).

P-67. Wilson, R.H., 1939, Rodents and Lagomorphs of the Late Tertiary Avawatz Fauna, Calif., Publ. Carnegie Inst. Wash. 514: 31-38.

P-68. , 1340, California Paramyid Rodents, Publ. Carnegie Inst. Wash. 514: 59-84.

* P-69. Woodburne, M.0., 1956, Equid Remains from the Sonora Volcanics, Calif., Bul1. S. Calif. Acad. Sci. 65: 185-189.

P-70. and Whistler, D.P., 1973, An Early Miocene Oreodont (Mierychinae, Mammalia) from the Orocopia Mountains, Southern Calif., Jour. Paleo., vol. 47, no. 5: 908-912.

P-71. , Tedford, R.H., and Stevens, M.S., et.al., 1974, Early Miocene Mammalian Faunas, Mojave Desert, Calif., Jour. Paleo., vol. 48, no. 1: 6-26.

* P-72. Yates, L.G., 1873, On the Occurrence of Remains of Fossil Elephans and Mastodons in Calif., Proc. Agassiz Inst., 1872, 61-63.

P-73. Zakrzewski, R.J., 1972, Fossil Microtines from Late Cenozoic Deposits in the Anza-Borrego Desert, California with the Description of a New Subgenus of Synaptomys, L.A.C.M. Contrib. Sci. 221, 12 pp.

P-74. Davis, E.L., 1978, The Ancient Californians., Nat. Hist. Mus. Los Angeles Co., Sci. Ser. 29: xi-193.

P-75. Huene, R. von, 1971, Fossil Mammals of the Indian lells Valley Region and How to Collect Them, Maturango Museum Publ. 5: i-18.

P-76. Stock, C., 1936, Titanotheres from the Titus Canyon Formation, California, Proc. Nat. Acad. Sci., 22: 656-661.

P-77. , and Bode, F.D., 1935, Occurrence of lower 01 igocene Mammal Bearing Beds near Death Valley, Calif., Proc. Mat. Acad. Sci., 21: $571-579$.

P-78. Evernden, J.F., and others, 1964, Potassium-argon dates and the Cenozoic Mammalian Chronology of North America., Amer. Jour. Sci., 262: 145-198.

P-79. Wilson, R.W., 1932, Cosomys, a new genus of vole from the Pitiocene of California. Jour. Manmalogy, 13: 150-154.

P-80. Schultz, J.R., 1937, A late Cenozoic Vertebrate Fauna from the Coso Mountains, Inyo County, California. Carnegie Inst. Wash. Putr. 487: $75-109$. 
P-81. Tedford, R.H., 1961, Clarendonian insectivores from the Ricardo Formation, Kern County, California. Bull. So. Calif. Acad. Sci., 60: $57-76$.

P-82. Buwalda, J.P., 1916, New mammalian faunas from Miocene sediments near Tehachapi Pass in the southern Sierra Nevada. Univ. Calif. Publ. Geol. Sci. 10: 75-85.

P-83. Smith, G.I., 1964, Geology and volcanic petrology of the Lava Mountains, San Bernardino County, California. U.S. Geol. Surv. Prof. Pap. 457: $1-97$.

P-84. Byers, F.M., Jr., 1960, Geology of the Alvord Mountain Quadrangle, San Bernardino County, California. U.S. Geol. Surv. Bull. 1089-A: $1-71$.

P-85. Bassett, A.M., and D.H. Kupfer, 1964, A geologic reconnaissance in the southeastern Mojave Desert, California. Calif. Div. Mines Spec. Rept. 83: 1-43.

P-86. Shreve, R.L., 1968, The Blackhawk 1andslide. Geol. Soc. Amer. Spec. Pap. 108: $1-47$.

P-87. Woodburne, M.0., 1975, Cenozoic stratigraphy of the Transverse Ranges and adjacent areas, southern California. Geol. Soc. Amer. Spec. Pap. 162: 1-91.

P-88. Woodburne, M.O., and D.J. Golz, 1972, Stratigraphy of the Punchbow? Formation, Cajon Valley, southern California. U.C. Publ. Geol. Sci., 92: 1-73.

P-89. Dibblee, T.I., Jr., 1968, Geology of the Fremont Peak and Opal Mountain Quadrangles, California. Calif. Div. Mines and Geol. Bull. 188: 1-64.

P-90. Dibblee, T.W., Jr., 1970, Geologic Map of the Daggett Ruadrangle, San Bernardino Co., California. U.S. Geol. Survey Misc. Geol. Invest. Map, scale 1:62,500. Map I-592.

P-91. Dibblee, T.W., Jr., 1953, Tertiary stratigraphic units of the western Mojave Desert, California. Amer. Assoc. Pet. Geol., Bul1., 42: $135-144$.

P-92. Dibblee, T.W., Jr., 1960, Geology of the Rogers Lake and Kramer quadrangles, California. U.S. Geol. Surv. Bull. 1089-B: 73-139.

P-93. Dibblee, T.W., Jr., 1963, Geology of the Willow Springs and Rosamond quadrangles, California. U.S. Geol. Surv. Bul1. 1089-C: 141-253.

P-94. Dibblee, T.'N., Jr., and A.M. Bassett, 1966a, Geologic map of the Newberry quadrangle, San Bernardino County, California.- U.S. Geol. Surv. Misc. Geol. Invest. Map I-461, scale 1:62,500. 
A-95. Dibblee, T.H., Jr., and A.M. Bassett, 1966b, Geologic map of the Cady Mountains quadrangle, San Bernardino County, California. IJ.S. Geol. Surv. Misc. Ge01. Invest. Map I-467, scale 1:62,500.

P-96. Noble, L.F., 1953, Geology of the Pearland quadrangle, California. U.S. Geol. Surv. Quadrangle Map, scale 1:24,000.

P-97. Noble, L.F., 1954, Geology of the Valyermo quadrangle, California. U.S. Geol. Surv. Quadrangle Map, scale 1:24,000.

P-98. Wood, H.E., III, and others, 1941, Nomenclature and correlation of the North American continental Tertiary. Geol. Soc. Amer. Bul11. 52: $1-48$.

P-99. Armstrong, R.L., and R.E. Higgins, 1973, K-Ar dating of the beginning of Tertiary volcanism in the Mojave Desert, California. Bull. Geol. Soc. Amer. 84: 1055-1100.

P-100. Whistler, D.P., 1967, Oreodonts of the Tick Canyon Formation, southern California. Paleobios. v. 1: 1-14.

P-101. Golz, D.J., 1976, Eocene artiodactyla of southern California. Nat. Hist. Mus. (Los Argetes) Bul1. 26: 1-85.

P-102. 01son, J.C. and L.C. Pray, 1954, The Mountain Pass rare earth deposits. Calif. Div. Mines and Geol. Bul1. 170, Chap. 8: 23-29.

P-103. Hewett, D.F., 1956, Geology and mineral resources of the Ivanpah Ouadrangle. U.S. Geol. Surv. Prof. Pap. 275: 1-172.

P-104. Dibblee, T.H., Jr., 1954, Geology of the Imperial Valley Region, California. Calif. Div. Mines and Geol. But1. 170, Chap. 2: 21-28.

P-105. Buwalda, J.P., and W.L. Stanton, 1930, Geological events in the history of the Indio Hills and the Salton Basin, southern California. Science, 71 : 104-106.

P-106. Crowe11, J.C., 1957, Structure of the Orocopia Mountains, southeastern California. Geol. Soc. Amer. Bul1. 68: 1712.

P-107. Crowe11, J.C., 1950, The San Andreas fault in southern California. Rept. 21st. Internat. Congress, Copenhagen, Pt. 18: 45-52.

P-108. Crowe11, J.C., 1962, Displacement along the San Andreas fault, California. Geol. Soc. Amer. Spec. Pap. $71,1-61$.

P-109. Crowe11, J.C., 1973, Problems concerning the San Andreas fault system in southern California. Stanford Uriv. Pubs. Geol. Sci., 13: 125-135.

P-110. Crowe11, J.C., 1974, The Orocopia thrust, southeastern California. Geol. Soc. Amer. Abs. with Programs, 6: 159.

P-111. Crowe11, J.C., and T. Susuki, 1959, Eocene stratigraphy and paleontology, Orocopia Mountains, southeastern California. Geol. Soc. Amer. Buli. 70: $581-592$. 
P-112. Spittler, T.E., 1974, Tertiary basaltic volcanism of the Orocopia Mountains, California. Geol. Soc. Amer. Abs. with Frograms, 6: 260.

P-113. Spittier, T.E., and M.A. Arthur, 1973, Post eariy Miocene displocement along the San Andreas fault in southern California. Stanford Univ. Pubs. Geol. Sci., 13: 374-382.

P-114. Crowe11, J.C., 1975, Geologic sketch of the Orocopia Mountains, southeastern California. Calif. Div. Mines and Geol. Spec. Rept. 118: 99-110. 


\section{$\underline{B} \underline{I} \underline{B} \underline{L} \underline{I} \underline{O} \underline{G} \underline{R} \underline{A} \underline{P} \underline{H} \underline{Y}-$ THESES}

* T-1. Barca, Richard A., 1961, Geology of the NorthernPortion of 01d Dad Mountain quadrangle, San Bernardino County, California, AM, USC.

T-2. Barnard, Ralph M., 1950, Geology of the Ricardo Beds in the Western portion of Salidale quadrangle, Kern County, California, AM, USC

* T-3. Blane, Robert P., 1958, Geology of the Deep Spring Valley Area, White-Inyo Mountains, California, MA, UCLA.

* T-4. Ceyion, Rasit, 1952, Geology and Ground Water Resources of Saltdale quadrangle, California, MS, USC.

T-5. Ellsworth, Elmer W., 1932, Physiographic history of the Afton Basin, San Bernardino County, California, PhD, Stanford.

* T-6. Evans, James R., 1958, Geology of the Mescal Range, San Bernardino County, California, MS, USC.

T-7. Fortsch, David E., 1972, A Late Pleistocene Vertebrate fauna from the northern Mojave Desert of California, MA, USC.

* T-8. Gardner, Dion L., 1933, Geology of the Newberry and Ord Mountains, Southeastern California, MA, UCB.

* T-9. Giles, Eugene, 1956, Multivariate Analys is of Pleistocene and Recent Coyotes in California, MA, UCB.

* T-10. Grose, Lucius T., 1955, Rocks and structure of the northeastern part of the Soda Mountains, San Bernardino County, California, PhD, Stanford.

* T-11. Groat, Charles G., 1967, Geology and Hydrology of the Troy Playa area, San Bernardino County, California, MS, Massachusetts.

T-12. Hami11, Gilmore S., IV, 1966, Structure and Stratigraphy of the Mt. Shader quadrangle, Nye County, Nye-Inyo County, California, $\mathrm{PhD}$, Rice.

* T-13. Haskel1, Barry S., 1959, The geology of a portion of the New York Mountains and Lanfair Valley, AM, USC.

T-14. Hayes, William H., 1957, Geology of the Central Mecca Hills, Riverside County, California, PhD, Yale.

T-15. Henshaw, Paul C., 1938, A Tertiary mammalian fauna from the Avawatz Mountains, California, MS, CIT.

T-16. Holwerda, James G., 1952, Geology of the Valyermo area, California, MA, USC.

* = reference of general interest, not tied to a particular fossil locality. 
page 17 BLANK 
* T-17. Hopper, Richard H., 1939, A geologic section from the Sierra Nevada to Death Valley, California, PhD, CIT.

T-18. Jefferson, George T., 1968, The Camp Cady local fauna from Pleistocene Lake Manix, Mojave Desert, California, MA, UCR.

* T-19. Jennings, Charles W., 1952, Geology of the Southern part of the Quail quadrangle, Los Angeles County, California, MA, UCLA.

* T-20. Johnston, Edward A., Geology of a part of the southeastern side of the Cottonwood Mountains, Death Valley, California, PhD, Rice.

T-21. Lindsay, E.H., Jr., 1967, Biostratigraphy of the Barstow Formation, Mojave Desert, PhD, UCB.

T-22. Lister, Kenneth H., 1970, Paleoecology of insect-bearing Miocene beds in the Calico Mountains, California, MS, UCLA.

T-23. Lanphere, Marvin A., 1962, Part I. Geology of the Wildrose area, Panamint Range, California. Part II. Geochronologic studies in the Death Valley - Majove Desert Region, California, PhD, CIT.

* T-24. McNeil, Mary Deligant, 1963, The Victorville pediment, San Bernardino County, California, its geology and climatic significance, MA, UCLA.

T-25. Fopenoe, Frank W., 1961, Geology of the southeatern portion of the Indio Hills, Riverside County, California, MA, UCLA.

* T-26. Ragan, Dorial M., 1954, Geology of Butte Valley, Inyo County, California, MS, USC.

T-27. Reynolds, Mitchell W., 1969, Stratigraphy and structural Geology of the Titus and Titanothere Canyon area, Death Valley, California, PhD, UCB.

* T-28. Richards, Carrol A., 1958, Geology of a part of the Funeral Mountains, Death Valley National Monument, California, MS, USC.

* J-29. Roberts, William B., 1951, Geology of a part of the Rosamond Hills area, Kern County, California., MS, CIT.

* T-30. Simpson, Edward C., 1933, Geology of the Elizabeth Lake quadrangle, California, PhD, UCB.

T-31. Smith, George I., 1956, Geology and petrology of the Lava Mountains, San Bernardino County, California, PhD, CIT.

T-32. Steinen, Randolph P, 1966, Stratigraphy of the Middle and Upper Miocene Barstow Formation, San Bernardino County, California, MA, UCR.

* T-33. Stirton, Ruben A., 1940, A phylogeny of North American Equidae with observations on the development of teeth, PhD, UCB. 
T-34. Stotts, John L., 1965, Stratigraphy and structure of the northwest Indio Hills, Riverside County, California. MA, UCR.

* T-35. Trowbridge, Arthur C., 1911, The geology of the Owens Valley, California with special reference to the terrestrial deposits. PhD, Chicago.

* T-36. Turner, Francis E., 1928, Geology of the Quail Lake Region. MS, CIT.

* T-37. Walker, George E., 1963, Geology and ground water of Amargosa Valley, Mevada and California, MA, OkTahoma.

T-38. Ware, Glen C., Jr., 1958, The geology of a portion of the Mecca Hills, Riverside County, California. MA, UCLA.

T-39. Whistler, David P., 1965, A new Hemingfordian (Middle Miocene) mammalian fauna from Boron, California, and its stratigraphic implications within the western Mojave Desert. MA, UCR.

T-40. Wilson, Robert W., 1936, Pliocene Rodents of western North America. Pho, CIT.

T-41. Winters, H.H., 1954, The Pleistocene fauna of the Manix Beds in the Mojave Desert, California. PhD, CIT.

T-42. Woodard:, G.D., 1963, The Cenozoic succession of the west Colorado Desert, San Diego and Imperial Counties, Southern California. PhD, UCB.

T-43. Whistler, D.P., 1969, Stratigraphy and small fossil vertebrates of the Ricardo Formation, Kern County, California. PhD, UCB.

T-44. Michael, E.D., 1960, Geology of Cache Peak, Kern County, California. MS, UCLA.

T-45. McCulloh, T.H., 1952, Geology of the southern half of the Lane Mountain Quadrangle, California. PhD, UCLA.

T-46. Miller, S.T., 1978, Geology and mammalian biostratigraphy of a portion of the northern Cady Mountains, Mojave Desert, California. MS, UCR.

T-47. Moseley, C.R., 1978, The geology of a portion of the northern Cady Mountains, Mojave Desert, California. MS, UCR.

T-48. Weber, G.E., 1962, Geology of a portion of the Indio Hills, Riverside County, California. Senior Thesis, UCR.

T-49. Wagoner, J.L., 1977, Stratigraphy and sedimentation of the Pleistocene Brawley and Borrego formations in the San Felipe Hills area, Imperial Valley, California, U.S.A. MS, UCR.

T-50. Dronyk, M.P., 1977, Stratigraphy, structure and a seismic refraction survey of a portion of the San Felipe Hills, Imperial Valley, California. MS, UCR. 
T-51. Woodard, G.D., 1963, The Cenozoic stratigraphy of the western Colorado Desert, San Diego and Imperial Counties, Southern California. PhD, UCB.

T-52. Spittler, T.E., 1974, Volcanic petrology and stratigraphy of nonmarine strata, Orocopia Mountains; Their bearing on Neogene slip on the San Andreas fault, southern California. MS, UCR.

T-53. Arthur, M.A., 1974, Stratigraphy and sedimentation of Lower Miocene nonmarine strata of the Orocopia Mountains; constraints for late Tertiary slip on the San Andreas fault system, southern California. MS, UCR. 


\section{A -13}

These are mainly general publications regarding areal! geology and mineral values.

I-1. Dibblee, T.H., Jr., 1967, Areal geology of the western Mojave Desert. U.S.G.S. Prof. Pap. 522: i-153.

1-2. Calif. Div. Mines and Geol., 1966, Mineral Resources of California. Calif. Div. Mines and Geol. Bul1. 191: 1-450.

I-3. Dibblee, T.H., Jr., 1952, Geology of the Saltdale Quadrangle, California. Calif. Div. Mines and Geol. Bul1. 160: 1-66.

1-4. Troxel, Bennie W., and Paul K. Morton, 1962, Mines and mineral resources of Kern County, California. Calif. Div. Mines and Geol., County report 1: $1-370$.

1-5. Wright, L.A., R.M. Steward, T.E. Gay, Jr., and G.C. Hazenbush, 1953, Mines and mineral deposits of San Bernardino County, California. Calif. Jour. Mines and Geol., 49; 1., 2: 49-192.

I-6. Wright, L.A., C.แ. Chesterman, and L.A. Norman, Jr., 1954, Occurrence and use of nonmetallic commodities in southern California. Calif. Div. Mines and Geol. Bull. 170, Chap. 8: 59-74.

I-7. Gardner, D.L., 1954, Gold and silver mining districts in the Mojave Desert region of southern California. Calif. Div. Mines and Geol. Bu11. 170, Chap. 8: 51-58.

1-8. Carlisle, D., D.L. Davis, M.B. Kildale, and R.M. Steward, 1954, Base metal and iron deposits of southern California. Calif. Div. Mines and Geol. Bul1. 170, Chap. 8: 41-50.

I-9. Bateman, P.C., and W.P. Irwin, 1954, Tungsten in southeastern California. Calif. Div. Mines and Geol. Bull. 170, Chap. 3: 31-40.

I-10. Mumford, R.W., 1954, Deposits of saline minerals in southern California. Calif. Div. Mines and Geol. Bull. 170, Chap. 8: 15-30.

I-11. Blackwelder, E., 1954, Pleistocene lakes and drainages in the Mojave region, southern California. Calif. Div. Mines and Geol. Bull. 170, Chap. 5: 35-40.

I-12. Blanc, R.P., and G.B. Cleveland, 1961, Pleistocene lakes of southeastern California II. Calif. Div. Mines and Geol. Mineral Inf. Service, $14(5): 1-6$.

I-13. Chesterman, W.D., 1956, Pumice, pumicite and volcanic cinders in California. Calif. Div. Mines and Geol. Bull. 174: 3-97.

I-14. Mason, J.F., 1948, Geology of the Tecopa area, southeastern California. Geol. Soc. Amer. Bul1. 59: 333-352.

I-15. Sheppard, R.A., and A.J. Gude, 1968, Distribution and genesis of authigenic silicate minerals in tuffs of Pleistocene Lake Tecopa, Inyo County, California. U.S. Geol. Surv. Prof. Paper 597: 1-38. 
I-16. Wright, L.A., 1974, Geology of the southeast quarter of Tecopa Quadrangle, Inyo County, California. Calif. Div. Mines and Geol. Map Sheet 20.

I-17. Izett, G.A., and C.W. Naeser, 1976, Age of the Bishop Tuff of eastern California as determined by the fission-track method. Geology, 4 (10): 587-590.

I-18. Buwalda, J.P., 1954, Geology of the Tehachapi Mountains, California. Calif. Div. Mines and Geol. Bul1. 170: 131-142.

I-19. Hunt, C.B., and D.R. Mabey, 1966, Stratigraphy and structure, Death Valley, California. U.S. Geol. Surv. Prof. Pap. 494-A.

I-20. Noble, L.F., and L.A. Wright, 1954, Geology of central and southern Death Valley region, California. Calif. Div. Mines and Geol. Bul1. 170, Chap. 2: 143-160.

I-22. Weber, Harold F., Jr., 1963, Geology and mineral resources of San Diego County, California. Calif. Div. Mines and Geol. County Rept. 3: 1-309.

I-22. Morton, Paul K., 1977, Geology and mineral resources of Imperial County. Calif. Div. Mines and Geol. County Rept. 7: 1-104. 
B. LOCATION MAPS FOR FOSSIL SITES OF VERTEBRATE FOSSILS IN THE CDCA.

These sites are portrayed on two maps of the CDCA, scale 1:250,000. The maps show three levels of probability for the occurrence of fossil vertebrates.

A. High Pobability. Such areas are colored blue, and, as discussed in the narrative, are based on the known occurrence of fossils, or are so designated because it is considered quite likely that fossils would be found there if careful searches were made.

B. Medium Probability. These areas are colored brown and are so designated because experience has shown that diligent searches can occasionally turn up fossil remains in sedimentary situations such as these.

C. Low Probability. These areas are colored yellow and are considered to be of low potential, but, because the distribution of fossil materials is unpredictable, these outcrops should not be ruled out entirely. Even in these areas, excavations for governmental or commercial purposes should still be proceeded by a survey by someone trained to recognize fossil materials.

D. Age. Rocks of different ages are outlined in red on the maps and labelled with symbols that correspond to the age assignments found on the appropriate map sheet of the Geologic Map of California. Figure B-1 shows the map sheets that are relevant to the CDCA.

In general, age designations are given as follows:

Q1 Quaternary Lake Deposits

Qt Quaternary Nonmarine Terrace Deposits

Qc Pieistocene Nonmarine

QP Plio-Pleistocene Nonmarine
All deposits labelled "Q" are of Quaternary age, that is, of Pleistocene to sub-Recent, or from about 1.8 million to as young as 5,000 years old. 


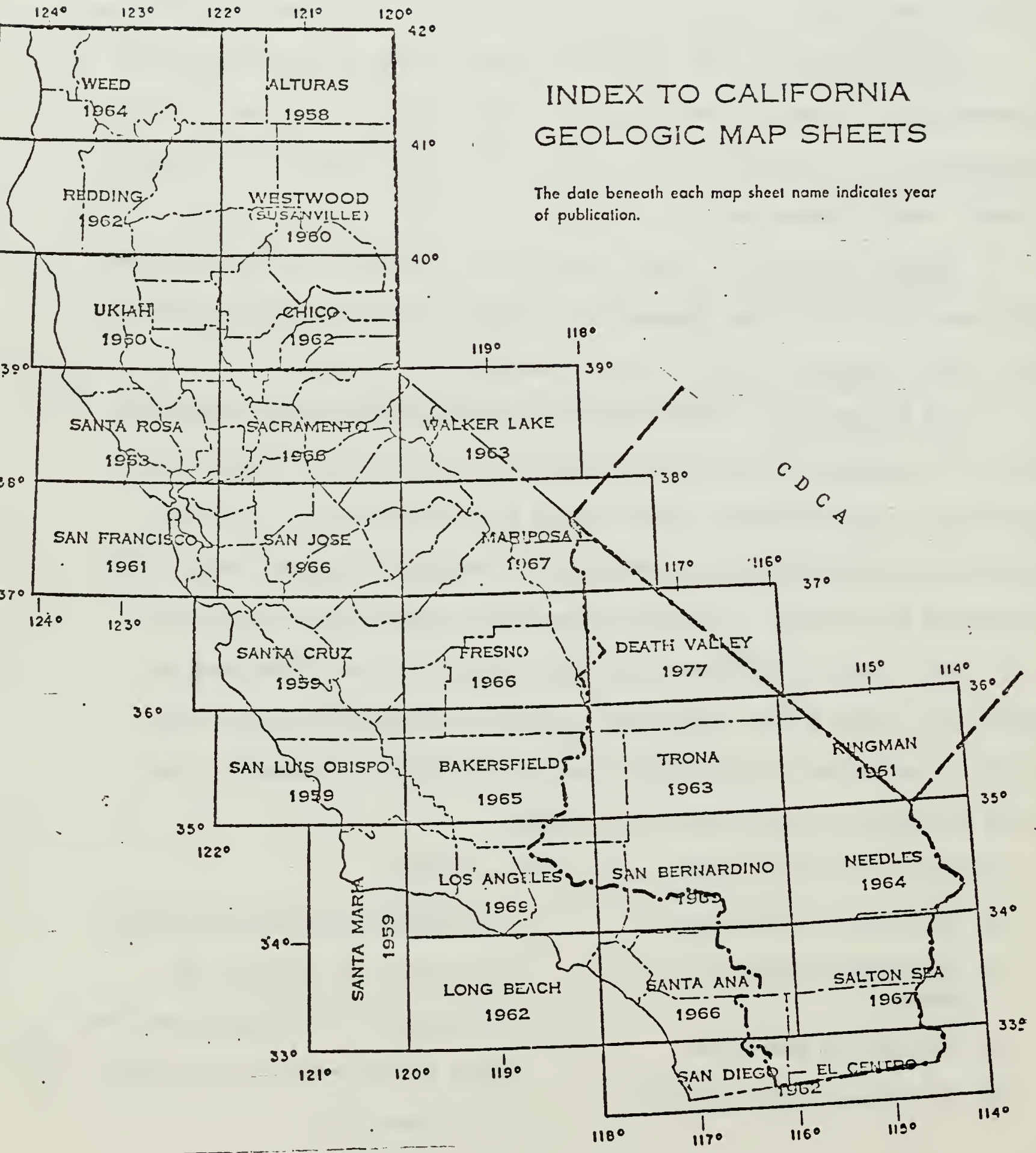


Pc Pliocene Nonmarine (sometimes with?) These rocks are all Tertiary

Mc Miocene Nonmarine (sometimes with ?) age, or from about 2 to 65

Øc 01 igocene Nonmarine (sometimes with ?) million years old (See Figure

Ec Eocene Nonmarine (sometimes with ?)

Epc Paleocene Nonmarine (sometimes with ?)

Tc Tertiary Nonmarine, more precise age not known

Tl Tertiary Lake Deposits, more precise age not known

Figure B-2 shows the difference between usage of words like "Pliocene" and "Miocene" at the time the geologic map sheets were prepared, and current usage. Based on work during mainly the last 10 years, the estimated age of certain intervals of Tertiary time, particularly the Miocene and Pliocene, has changed. Some sediments, and also their fossils, once called Pliocene would now be designated as Miocene. The labels on the maps will provide a good estimation of the age of the rocks, and if more precision is required, consultation with Figure $B-2$ will give a reliable estimation of the current consensus. Thus, under the former. scheme, rocks designated as of Pliocene age could be considered to be as much as about 11 million years old. Rocks that old would now be considered to be of Miocene age, whereas Pliocene rocks and fossils would not be older, than about 5 million years.

E. Mammal Ages. The subdivision of Cenozoic time (Tertiary plus Quaternary) for nonmarine sediments in North America is commonly done with reference to intervals known as Mammal Ages, because these are locally devised segments of time based on the evolution of fossil mammals. Use of mammal ages is preferred, when precision is desired, because use of words like Miocene and $\mathrm{Pliocene}$ entail a certain amount of correlation from North America to rock and fossil sequences in Europe where Cenozoic Epochs were filut named (and based there on marine invertebrates rather than nonmarine 
mamma ls).

In the narrative of Section C, Mammal Ages are used, along with the age symbol that appears on the maps. Thus, the early age reference is preserved, and will aid in locating the area in question on the map; at the same time, an updated estimation of the age of the fossils and strata will be given. 


\section{Stte of Potential Outdoor Museum}

This site, located in OWI Canyon area of the Mud Hills (no. 23, Section C), contains trackways made by a camel. I last saw these a few years ago, and if memory serves, they were located in the SE $1 / 4$, NW 1!4, SW 1/4, sec. 19, T. 11 N., R. 2 W., Opal Mountain Quadrangle, $1: 62,500$, 1955ed. The tracks occurred on the underside of a bed of tuff, and are located in a side canyon not often frequented by tourists. Other trackways in the area were previously visible, but have since been destroyed by erosion or by rock haunds, or both. It might be possible to enclose this area with heavy plactic sheets or some such means, and install an informative placque telling something about the tracks and their history. In my opirion, based on experincice in other areas, the site would be destroyed or defaced in a relatively short period of time unless it was given 24 hour supervision. Unfortunately, these trackways, if they still exist, do so because the general public.doesn't know what they are, or if someone happens, to see the tracks, he doesn't recognize them for what they are. 


\section{MORPHOLOGIC AND LITHOLOGIC DESCRIPTION OF FOSSIL BEARING OUTCROPS}

IN THE CDCA

This section also includes information relative to section $E$ (ranking for research, education, recreation, industrial potetntial). It also includes a cross index in the text for each locality in terms of map location, institutions with collections, and bibliography. This accounts for items specified in section I.

Ranking.-- The following comments explain the ranking levels of the various categories.

Research.-- Fossils are important from a number of points of view. In and of themselves, fossil remains can be interpreted as to their evolutionary level, and by their sole existence represent tangible evidence that a certain kind of animal lived at this particular place (or was at least buried there, and lived somewhere in the vicinity). Fossils are normally identified to several taxonomic categories, for example, Class Mamalia, Order Carnivora, Family Canidae, Genus Canis, species latrans (=Coyote). It commonly requires progressively more material to allow an identification at successively smaller (from the Class towards the Species) taxonomic levels, but for certain, especially geographic, studies it may be important to know that a particular Order or Family was present in a certain area at a certain time. Even if identifiable only as Mammalia, the fossil at least shows that bones are capable of preservation in a certain deposit, encouraging further search if such is scientifically warranted. As the completeness of material increases (from just fragments, up to complete skeletons) or the abundance of fossils increases, so does the research value of a site. Because fossils can be studied from so many different viewpoints (stratigraphic, environmental, evolutionary, populational, nature of accumulation, etc., the most flexible scheme seems to be a two-fold classification. In the following 
pages, the research value of a site is designated as:

RI High research value; reasons specified.

R2 Low research value; reasons specified.

Education.-- The education value of a site is closely related to its research value. Once fossils are recovered, prepared, studied, and reported on in scientific or popular literature, or put on display, the educational value is clearly seen. Except in unusual circumstances, (see Section J), fossils must be removed from the ground. There may be more fossils at the site in question, but the educational value is rormally associated with the ability of interested students or professionals, as well as general public, to be shown where certain kinds of fossils have been obtained. The visitor can then be aware of the sedimentary, stratigraphic, geologic environmental, etc., conditions under which the specimens were preserved and how they were arrayed in the rock column. Sites, themselves, rather than the fossils which have been obtained from them, commonly have less educationa? value to the general public than to the student or professional. If educational value accrues to a site from a different (non-fossil) viewpoint, that is noted.

El High educational value; reasons specified.

E2 Lower educational value; reasons specified.

Recreation.-- Finding fossils is fun, and so is collecting them. Because of their fragile, unique nature, however, (Section J) collecting should be done by someone who knows how to do it correctly, and how to record the additional kinds of data that allow the specimen to be significantly tied to its stratigraphic location. This usually means a professional, or someone working under the supervision of a professional. Furthermore, the Federal Antiquities Laws prohibit the collecting of fossils without a proper permit, and such permits are awarded only to institutions, or qualified individuals 
associated with such institutions, who are engaged in scientific research and who, once the specinens have been collected, will see to it that they are given the necessary care and attention to ensure continued availability to the professional worker or member of the general public.

For these reasons, my interpretation is that fossils generally have no recreational value, in the generally accepted definition of the term. A few exceptions might be areas where a permanent exhibit has been constructed to preserve specimens in place, and where such an exhibit is provided with the necessary security. As mentioned in Section $J$, this has been successfully accomplished only one or two places. At present, sites in the CDCA that could be developed for permanent display are rare. I know of only one or two, and these will be indicated. Most sites will be designated:

RO Low recreational value, in the sense described above.

RP Potential recreational value, reasons specified

If other (non-fossil) recreational value accrues to a site, that is noted. Industrial.-- It is almost a contradiction in terms to discuss the industrial potential of a fossil-bearing site. Over the years, many more people havd been scouring the CDCA for mineralogic or geothermal resources than have been looking for fossils. Commonly, fossils are found during industrial exploration. Except for the newer aspects of energy technology, such as locating solar power generating and testing facilities, I believe that most of the industrial potential of the CDCA is known, and such sites are commoniy not those that would be expected to bear fossils. An exception is the U.S. Borax Mine near Boron (Map 1), where fossils were discovered in the borateproducing sediments. Solar power generating or testing facilities can, theoretically, be built nearly any place that receives a lot of sunlight. Presumably, it also would be better if the site were fairly flat, and near a dependable water supply, i.e., reasonably near a city. At any rate, the 
conditions that must be met to allow a site to have good potential for this type of industrial use has nothing to do with the fact that it also produces fossils.

I claim no expertise in the siting of solar or geothermal power plants, pipe lines, power lines, and, as mentioned above, believe that essentially all in-the-rock industrial values have been previously ascertained. Various agencies are now investigating the CDCA for its uranium potential, and presumably this information will be available eventually. I presume that there will never be a nuclear power generating facility in the CDCA, because of the insufficient water supplies, except near the Colorado River.

For the reasons given above, all fossil-producing sites in the CDCA are given a low industrial potential, unless there is specific reason to do otherwise.

I1 High industrial potential

I2 Low industrial potential 
Map 1

1. Grapevine Mountains. Øc; OTigocene; Chadronian.

The deposits consist of a variegated succession of quartzite, sandstone, calcareous mudstone, algal limestone and tuffaceous sandstone in a rugged terrain of relatively deep, steep-sided canyons. The outcrops occur near the California-Nevada border in the Grapevine and Funeral Mountains, on the east side of Death Valley. The sediments reach a thickness of as much as 7,000 feet, generally dip eastward to northeastward, and unconformably overlie marine rocks of Paleozoic age (Cambrian to Permian). Conglomerates and rhyolitic volcanic rocks of possible Miocene age unconformably overlie the 01 igocene sediments.

Fossils.-- Up to now, the fossils have been recovered mostiy in the vicinity of Leadfield, in an interval about 100 feet thick, about 500 feet above the basal unconformity. The material is sparse, but significant in that this is one of the few areas in all California that has produced fossil mammals of 01 igocene age. For this reason, all of the outcrops of these rocks have been designated as high potential and significance. Paramyine, aplodontid, canid, Mesohippus, Eotrigonias? mortivallis, Protoreodon transmontanus,

Poabromylus? robustus, Leptomeryx blacki.

References.-- Death Vàlley Sheet (all subsequent use of "Sheet" refers to the Geologic Map of California); P-33 (a11 "P" and "T" notations refer to the Bibliography of Publications and Theses. "I" notations refer to Miscellaneous Publications List. These are all found in Section A.). P-53, $P-58, P-76, P-77, P-101, T-23, T-27, T-28, I-2$.

Institutions with major collections.-- Natural History Museum, Los Angeles. 
Values.-- Research; R1. See above.

Educational; EI. for students and professionals. The area is an excellent one to conduct stratigraphic field trips.

Recreational; Ro. The area is quite scenic, but also very difficult to get to. The present one-way road through Titus Canyon probably meets present needs.

Industrial; I2. None known. 
Map 1

2. Coso Mountains. QP: Plio-Pleistocene; Blancan.

The deposits consist of about $300^{\prime}$ of conglomeratic to pebbly, grayish brown, tan, to greenish brown, arkosic to tuffaceous, coarse- to finegrained sandstone, with subsidiary amounts of siltstone. The deposits include white to brownish gray tuffs dated at 2.1 and $2.3 \mathrm{m.y}$; these occur stratigraphically above the fossil localities. The sediments are overlain by flows of basalt, 50 to 100 feet thick, and unconformably overlie pre-Tertiary granitic rocks. The exposures occur in a gently rolling topography, cut by narrow canyons, on the northwestern and western flanks of the Coso Range, southeast of Owens Lake.

Fossils.-- Most of the fossils have been found in the northwestern part of the area, but there is great potential for all of the district; all outcrops are rated as of high potential and significance. This area produces fossil mammals of early Pleistocene or latest Pliocene age, and is one of the very few such localities in southern California. As such it should be carefully preserved rather than being used as a site for motorcycle races, as happened recently. Cosomys primus, Hypolagus? limnetus, Borophagus solus, Platygonus, Hemiauchenia, Plesippus francescana, Pliomastadon? cosoensis.

References. -- Death Valley Sheet; P-79, P-80, P-75, T-35, I-6. Institutions with major collections.-- Natural History Museum, Los Angeles; Museum of Paleontology, University of California, Berkeley. Values.-- Research; R1. (See above).

Educational; E1. For students and professionals.

Recreational; RO. Because of the scientific value, ORV races should not be conducted here.

Industrial; 12. Punmicite mines occur about 3 miles east of the southern part of the outcrop area, but none occur in it. 5 miles to the 
north are salt wells in Owens Lake, and a salt products plant occurs 7 miles north of the fossil beds. 
Map 1

3. Tecopa Lake Beds. Q1; Quaternary; Irvingtonian. Also QC, see below. These beds consist of lacustrine siltsone and mudstone, generally drab brown, gray, or green in color, interbedded with layers of tufa and ash. They are nearly flat-lying, and attain a thickness of $100-200^{\prime}$. Three major tuff units have been identified, $A$ to $C$, top to bottom. Tuff $B$ has been correlated with the Bishop Ash, dated radiometrically at about 700,000 years. Tuff $C$ has been correlated on the basis of trace element content with tuffs in the Ventura Basin that are older than 1.2 million years. The associated fauna, that occurs about $24^{\prime}$ below Tuff $C$, is of Irvingtonian age, consistent with a correlation of older than 1.2 million years, but probably younger than 2 million years.

The Tecopa deposits occur in a wide area east and north of Tecopa Hot Springs, between the Resting Springs Range, and the Dublin Hills.

Fossils.-- The fossils have been recovered mainly from exposures a few miles east of Tecopa Hot Springs, but scattered finds occur to the west and north, as well; so all of these deposits, and the fringing Quaternary conglomeratic beds (QC) are rated as of high potential and significance. This area is one of only two places in California that produce good examples off small mammals of Irvingtonjan age. In addition, it has yielded remains of an unique camel-like animal, unknown elsewhere. These finds are particularly important because of their association with the tuffs mentioned above. ?Titanotylopus, Mammuthus, Lepus. Sorex, Dipodomys, Reithrodontomys, Sigmodon, Neotomodon, Neotoma, Zapus.

References.-- Trona Sheet; I-11, I-12, I-13, I-14, I-15, I-16, I-17. Institutions with major collections.-- Natural History Museum, Los Angeles; Department of Earth Sciences, University of California, Riverside. 
Values.-- Research; RI. (See above)

Educational; E1. For students and professionals; stratigraphy, sedimentation, lake history.

Recreational; RO. ORV use should be discouraged because of high research value.

Industrial; 12. Colemanite deposits are known from the vicinity of Shoshone, and borate deposits were once mined from a number of places in greater Death Valley. None are currently being mined in the immediate Tecopa area, to my knowledge. The Nopah Range, 5-7 miles to the southeast, has produced lead, zinc, silver, talc; the Ibex Hills to the southwest, have produced lead, zinc, and silver. 
Map 1

4. Indian Wells Valley. Q1; Quaternary; Irvingtonian. Qal; Quaternary; Rancholabrean.

An extensive succession of white to pale green fine-grained, lacustrine sandstone and siltstone crops out in Indian Wells Valley. The beds are generally flat-lying, but arelocally tilted, probably in response to faulting. In most cases their base is not exposed, but locally the sediments rest unconformably on pre-Tertiary granitic rock. The deposits are most extensively exposed in the north-central part of the valley, where they are overlain by Late Pleistocene basalt.

The relief is generally low, but occasional badland areas of higher elevation are preserved.

Fossits. - - These mammals fossils occur mainly in the vicinity of Airport Lake, in the White Hills, in the northern outcrop area, but also have been recorded from areas west and northwest of China Lake, to the southeast. All of the lake deposits in the Indian Hills Valley are regarded of high potential and significance. Irvingtonian: Paramylodon, Stegomastodon, Mammuthus, Equus, Camelops, Breameryx. Rancholabrean: Canis, Smilodon, Equus, Hemiauchenia, Camelops, Odoeoileus, Bison, Mammuthus, Microtus.

References.-- Trona Sheet; P-74, P-75, T-7, I-2. Institutions with major collections.-- Natural History Museum, Los Angeles; Department of Earth Sciences, University of California, Riverside. Values.-- Research; R1. Even though the sites are located on the Naval Ordnance Test Station and access is restricted, they are regarded as important in containing the only information on Irvingtonian and Rancholabrean succession, as. to past life of this area, and the association of fossil humans with the latter.

Educational; E1. For students and professionals, could 
be of high significance in displaying archaelogical methodology.

Recreationa 7; RO. Particularly in view of restricted areas.

Industrial; I1. Borates are mined from China Lake. A tungsten mill operates on Brown Hill, northwest of China Lake. Gold mines occur in the Argus Range to the east, but are mostly inactive. 
Map 1

5. El Paso Mountains. Epc; Paleocene; Torrejonian, and PC; PTiocene; Clarendonian. (On. the Trona Sheet of the Geologic Map of California, Pc is labelled Pmic - middle and/or lower Pliocene. In modern terms - Figure B-2 these rocks are upper Miocene.)

Two important fossil-bearing rock units are exposed in the El Paso Mountains, which rise just north of the Garlock Fault and extend northeastward from the vicinity of Red Rock Canyon State Park for a distance of about 20 miles. The southeastern face of the range front is relatively steep, and traversed by narrow canyons, whereas to the northwest, the topography is generally smoother, with broadly open valleys.

The Goler Formation (Paleocene) is at least 6,500' thick, and consists of buff to red conglomerate and conglomeratic arkosic sandstone interbedded with drab green to brown fine-grained sandstone and siltstone; cobbles in the conglomerate are generally smoothly rounded clasts of quartzite, chert, and granitic rock, along with hornfels and porphyritic volcanic rock. The beds unconformably overlie the Permian Garlock Formation, and are unconformably overlain by Pliocene Ricardo Formation.

Fossils.-- These are mainly known from the vicinity of Goler Gulch in the northeastern part of the range, but because of their significance, all exposures of the Goler Formation are deemed highly important. This is the only area in the Southwestern United States from which Paleocene mammals are known. Neoliotomus cf. coventus, Tetraclaenodon puercensis.

References.-- Trona Sheet; P-31, P-32, P-62, I-3. Institutions with major collections.-- Museum of Paleontology, University of California, Berkeley. 
The Ricardo Formation (Pliocene; Clarendonian) is most extensively developed in the Red Rock Canyon State Park - Last Chance Canyon district, in the southwest part of the range, but also extends northeasteward to the vicinity of Goler Gulch. The Ricardo Formation unconformably overlies the Goler Formation, and is usually less steeply deformed. The Ricardo is about $6,200^{\prime}$ thick in the Red Rock Canyon area, but thins to the southwest and northeast, and is composed of a succession of varicolored nonmarine sediments that range from arkosic conglomeratic sandstone to siltstone interbedded with tuffs and flows of basalt and andesite. In the middle 3,000' of section, calcareous, fine-grained sediments (typically seen in Last Chance Canyon) interfinger from the north and northeast with a unit of coarsergrained rocks (typically seen in Red Rock Canyon) that thickens to the southwest. Above the fine-grained rocks are mainly coarse-grained clayey siliceous sandstone beds. The sediments are unconformably overlain by alluvium and Pleistocene Black Mountain Basalt.

Fossils.-- The Ricardo Fauna was one of the first described from the Mojave Desert Region, and has come to typify late Miocene mammalian life in Southern California. Because of work conducted in recent years, mainly by personnel now at the Natural History Museum, Los Angeles, the fauna is well represented by both large and small mammals, and is one of the few wellbalanced Calrendonian faunas in North America. Paradryosorex chasseae, Sorex, Scapanus schultzi, Leptocyon vafer, Aelurodon aphobus, Osteoborus ricardoensis, 0. diabloensis, Tomarctus robustus, Ischyrocyon mojavensis, Bassariscus, Mustela? buwaldi, Albanosmilus osborni, ?Pseudaelurus, ?Spermophilus,

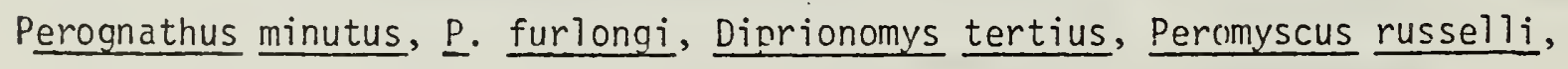
Copomys, Hypolagus, Gomphotherium, ?Serbelodon burnhami, Aphelops, Peraceras, ?Hypohippus, Hipparion mohavense, $\underline{H}$. forcei, Neohipparion, Pliohippus tantalus, P. fairbanksi, P. cf. tehonensis, P. cf. leardi, Ustatochochocrus californicus, 
U. cf. medius, Peccary, ?Procamelus, ?Megatylopus, Cosoryx furlongi, ‥ cf. recatus, Sphenophalos (Plioceros).

References.-- Trona Sheet; P-31, P-32, P-35, P-38, P-51, P-53, P-62, P-78, T-53, I-1, I-3.

Institutions with major collections.-- Natural History Museum, Los Angeles; Museum of Paleontology, University of California, Berkeley; Department of Earth Sciences, University of California, Riverside.

Values.-- Research; RI (See Above).

Educational; El. Students and professionals, for studies on stratigraphy, general geology, location of important fossil-bearing sequences.

Recreational; RO. The area is somewhat difficult to get through, unless 4-wheel drive vehicles are available; 1 imited ORV use probably should be allowed, but certainly not massive use. Semi-precious stones may be found in the area.

Industrial; I2. Placer gold, pumice, pumicite and clay are the principal products. Lode gold, coal, and copper have been mined, also. Prospects for lead, uranium, molybedenum, and perlite have been explored and it is possible that ornamental stones may be quarried. Fire opal, jasper, agate, and silicified palm are often collected from the northwestern part of the area. Several hundred thousand dollars worth of metals and nonmetals have been removed. Potential for further riches is low. 
Map 1

6. Eastern Tehachapi Mountains. Muc; Miocene; Hemingfordian and Barstovian. (MC is labelled Muc - upper Miocene nonmarine - on the Bakersfield sheet of the Geologic Map of California)

Two rock units - the Kinnick and Bopesta formations - are exposed on and around Cache Peak, in steep, rugged terain. The Kinnick Formation, $1,500^{\prime}$ thick, consists of stratified green volcanic tuffs, largely ash beds, woth some coarse agglomerate; the upper part of the formation is gray sandy shale and, locally, white, freshwater diatomaçeous beds and cherts. The unit unconformably overlies the Witnet Formation, and pre-Tertiary basement. It is conformably overlain by the Bopesta Formation, and interfingers with andesites of the Cache Peak area.

Fossils.-- The fossils comprise the Phillips Ranch Fauna, which are associated with plants (Tehachapi Flora) and tuffs dated at 17.1 m.y. Merychippus tehachapiensis, came1, Moropus, ?Merycodus, Cyporca sociale. References.-- Trona and Bakersfield Sheets; P-5, P-82, T-44, I-1, I-2, I-3.

Institutions with major collections.-- Natural History Museum, Los Angeles; Museum of Paleontology, University of California, Berkeley.

The Bopesta Formation overlies the Kinnick, is about 2,800' thick, and consists of tan, white, fine- and coarse-grained tuffaceous sandstone, some interbedded conglomerate and gray sandy shale. In the south, the lower beds are olive-green siltstone, platy semi-siliceous shale, sandstone and basalt. To the north, the formation intertongues with and is overlain by andesites of the Cache Peak area.

Fossils.-- These are the Cache Peak Fauna of Barstovian age. Both the Cache Peak and the Phillips Ranch Faunas are in need of further collection and study. Together they constitute one of the few places in the Mojave 
Desert Region where it is still possible, with new collections, to investigate the evolutionary change from Hemingfordian to Barstovian ages mammals. Merychippus cf. stylodontus, Merychyus, camel, Dromomeryx, Merycodus. References.-- Trona and Bakersfield Sheets; P-5, P-82, T-44, I-1, $I-2, I-3$.

Institutions with major collections.-- Museum of Paleontolgy, University of California, Berkeley, Natural History Museum, Los Angeles. Values.-- Research; R1. (See above)

Educational; El. Students and professionals; stratigraphic. demonstration of boundary between two mammal ages, in this case, Hemingfordian and Barstovian.

Recreational; RO. There has been some "rock hound" activity for semi-precious stones, but most of this land is privately owned, and access is limited.

Industrial; 12. Especially in the vicinity of Cache Peak, claims for various minerals are abundant; gold, perlite, clay, semi-precious minerals. To the southwest, near Cache Creek, 3 mile north of Route 466, roofing aggregate quarries supply gravel to aggregate mills. These are not closely located to fossil sites, however. 
$\operatorname{Map} 1$

7. Garlock. Qc; Quaternary; Rancholabrean

The fossils occur in Quaternary sediments south of the Garlock fault and a little west of Garlock.

Fossils.--Sparse remains of bird, rabbit, Equus, indicate the age of the beds and, inasmuch as they are cut by it, the recency of activity of the Carlock fault.

Reference.--Trona Sheet; records of the Natural History Museum, Los Angeles, CIT 483a.

Institution with major collection.--See Referenc..

Values.--Research; R2. This is based on the sparse nature of the fossils; additional collecting could change this reference.

Educational; E2. See above.

Recreational; RO. Probable ORV activity, rock hounds. Industrial, I2. Low potential. 
Map 1

8. Lava Mountains. PC; Pliocene; Clarendonian (These exposures are labelled Pmlc - middle and/or lower Pliocene nonmarine - on the Trona Sheet of the Geologic Map of California. In modern terms, these sediments rse upper Miocene in age.)

The sediments, the Bedrock Spring Formation, are exposed along the northern flank of the Lava Mountains, and form locally rugged badland topography, but generally occur within fairly open valleys. The sediments are about 5,000' thick and consist of coarse-grained arkosic conglomerate, sandstone, siltstone and claystone, with lesser amounts of limestone, evaporite deposits, tuff, tuff breccia, rubble breccia, and lapili breccia. The formation unconformably overlies various older rocks - pre-Tertiary metamorphic rocks, Atolia Quartz Monzonite, and Tertiary volcanic and sedimentary rock. The Bedrock Spring Formation is unconformably overlain by the Almond Mountain Volcanics, and locally the Lava Mountains Andesite and Quaternary andesite gravel.

Fossils.-- The fossil are sparse, but important in establishing the age of the deposits, which could be equivalent to the Ricardo Formation of the El Paso Mountains to the north, and offset from them by left lateral slip on the Garlock Fault. Fossils can be found throughout the length of the exposures. Neotomodon, Hypolagus, Leptocyon vafer, Gomphotherium, ?Megatylopus, ?Pliauchenia, Pliohippus cf. leardi cf. Aphelops, Merycodus.

References.-- Trona Sheet; P-83, T-31.

Institutions with major collections.-- U.S. Geological Survey, Denver; Department of Earth Sciences, University of California, Riverside.

Values.-- Research; R1. Only preliminary searches for fossil mammals have been made in this area. There is a definite potential to develop a stratigraphically controlled array of localities, some of which already have been 
shown to produce smal1 as well as larger vertebrates.

Educational; E1. Students and professionals, to evaluate the above and also the regional correlation with the possibly offset counterpart, The Ricardo Formation.

Recreationa 1; RO. There is some "rock hound" activity for semi-precious stones; fossils probably are found occasionally and illegaliy collected, or destroyed.

Industrial; I1. This area is partly in, or adjacent to, the Lava Mountains Geothermal exploration area. Any excavations or other activities associated with drilling or exploration procedures should be preceeded by a survey for fossil vertebrates.

Farther to the west, numerous lode gold claims occur in and around Randsburg-Johannesburg, as well as claims for manganese and silver. A few are still being worked. 
$\underline{\text { Map }} \underline{1}$

9. Avawatz Peak. TC; Tertiary; Clarendonian.

The Avawatz Formation occurs in rugged canyon-land exposures on the southern and southwestern flank of Avawatz Peak, and the correlative deposits have been recorded along slivers of the Garlock Fault Zone to the northwest, and of the Death Valley Fault Zone to the north. These deposits, usually tilted and folded, consist of a basal interval about 1,000' thick, composed of coarse-grained conglomerate, some of which is monolithologic. These beds are overlain by a middle unit of interbedded claystone, sandstone, and coarse- to fine-grained conglomerate. Green, gray-green, and browngreen to brown fine-grained sandstone and claystone predominate. An interval of coarse-grained breccia overlies the claystone section; 'and individual breccia beds are several meters across. The upper part of the formation consists of arenaceous clastic sediments and some tuff, with coarse-grained sandstone at the top. Tuff beds in this interval have been dated at 10.7 and $11.0 \mathrm{~m} . \mathrm{y}$.

Fossils.-- The Avawatz fauna occurs in the upper unit and is of Clarendonian age. Pseudaelurus intrepidus, Perognathoides cf. tertius, Peromyscus dentalis, Hypolagus, Gomphotherium cf. simplicidens, Pliohippus, Procamelus coartatus, Merycodus cf. corroensis.

References.-- Trona Sheet; P-17, P-78, T-17, I-5

Institutions with major collections. -- Natural History Museum, LoS Angeles; Museum of Paleontology, University of California, Berkeley; Department of Earth Science, University of California, Riverside; R.M. Alf Museum, Webb School, Claremont, CA.

Values.-- Research; R1. This area is quite important in that the fauna is associated with potassium-argon dates, and the sedimentary record probably reflects the beginning or at least early phase of the uplift of the 
Avawatz Mountains, and possibly the local age of movement of the Death Valiey and Garlock Fault Zones.

Educational; E1. Students and professionals, primarily from the viewpoint of the stratigraphy of the rocks, the association of fossils and potassium-argon dates; exercises in structural geology; depositional mechanics; sedimentology. The rocks are locally quite structurally deformed, and also show interesting problems in depositional mechanics in that large monolithologic megabreccia masses have been emplaced in the very finegrained sedimentary sequence with little apparent deformation of the underlying materials.

Recreational; RO. The area shows some locally interesting scenery, but is difficult to get into.

Industrial; 12. Iron Mountain and Iron King claims (iron ore) are situated along the southern contact of the fossil-bearing beds, south of Silver Lake Road. Kaiser Steel considered these too remote for operation at present. 
Map 1

10. Salt Spring Hills Playa. Q1; Quaternary; Pleistocene.

Playa lake sediments in playa east of Salt Spring Hills.

Fossils.-- Bones have been reported but not collected.

References.-- Trona Sheet; San Bernardino County Museum, reference

1.67.1.

Institutions with major collections.-- None.

Values.-- Research; R2. At least until a high concentration of fossils can be demonstrated.

Educationa1; E2. Nothing extraordinary seems to be associated with these playa sediments.

Recreational; RO. This playa is too small and isolated to have any significant recreational use.

Industrial; 12. Nothing significant is known, but the area occurs in one of the msjor talc producing regions in the United States. 
Map 1

11. Sperry Wash Railroad. QP; Quaternary; Pleistocene; Rancholabrean.

Fluvatile gravels and sandstone, along the old railroad grade about 1. mile north of Sperry Wash Road.

Fossils.-- Bison tooth seen, not collected.

References.-- Trona Sheet; San Bernardino County Museum reference 1.67.2.

Institutions with major collections.-- None.

Values.-- Research; R2. Unless a greater concentration of fossils

is found. These playa deposits, however, indicate something about the Quaternary history of the area, possibly as a marginal facies of the lacustrine sediments that developed in these areas during the Pleistocene. If not connected with Lake Manly, and others that extended from Owens Valley, through Manix Lake, to Death Valley, the greater Tecopa lake system was coveal with the others.

Educationa7; E2. Mainly because of sparse information as to fossils. If this became better known, so as to more adequately correlate the deposits with those in the Tecopa Basin, and elsewhere, this could be an interesting one to study.

Recreational; RO. Nothing exceptional is known for the area; the old railroad line, and some talc mines in the area provide some interest.

Industrial; 12: Talc mines occur in the area, and some, such as the Western or Acme Mine, are still in operation. 
Map 1

12. Superior Dry Lake West. Q1; Quaternary; ?Rancholabrean.

Playa lake beds, near southest shore of Superior Dry Lake, SE $\frac{1}{4}$,

$N E^{\frac{1}{4}}$, sec. $23, T .31$, R. $45 \mathrm{E}$.

Fossils.-- bone and tooth fragments.

References.-- Trona Sheet; San Bernardino County Museum reference

$1-134-1$.

Institutions with major collections.-- San Bernardino County Museum, Redlands CA.

Values.-- Research; R2. Until greater concentration of fossils is shown.

Educationa 1; E2. Nothing important distinguished this playa from others.

Recreationa 1; RO. No particularly interesting factors are shown.

Industrial; I2. A few unidentified claims are located near the base of slocum Mountain, to the northwest; apparently inactive. 
Map 1

13. Jack Rabbit Spring. Q1; Quaternary; ?Rancholabrean.

Immediately northeast of road, $700^{\prime}$ southwest of spring, northern end of Coyute Dry Lake. Playa Lake deposits.

Fossils.-- Fossil camel bones reported, not collected.

References.-- Trona Sheet; San Bernardino County Museum reference 1.75 .1$.

Institutions with major collections.-- None

Values.-- Research; R2. Until greater concentration of fossil is shown.

Educational; E2. Because of the poor present level of information. However, these deposits probably are equivalent to, or are part of, the Manix Lake Beds, which formed 20-30,000 years ago.

Recreational; Ro. Nothing important known.

Industrial; Mainly 12. Five miles northeast are the Daisy and olympus gold mines, now inactive. The Starbright Tungsten Mine, 10 miles west, is actively producing scheelite. Ten miles southeast, the Alvord Mine (gold) operated as recently as 25 years ago. 
-Map 1

14. Fort Irwin Playa. Qal; Alluvium; Rancholabrean?

Sediments not distinguished from Qal on Trona Sheet of Geologic

Map of California; see Red Pass Lake 15' Quadrangle, secs. 31 and 32, T. $16 \mathrm{~N}$, R. 5 E., small playa shows along road at that scale.

Fossils.-- Mammoth tooth fragments observed, not collected.

References.-- Trona Sheet; San Bernardino County Museum reference

1.153.1.

Institutions with major collections.-- None.

Values.-- Research; R2. Until more can be known, the research potential here is low.

Educational; E2. For same reasons as above.

Recreational; RO. Access is limited because site occurs on military reservation.

Industrial; I2. Surely, This place is too small to have any significance. Eight miles west, the Gold Divide Tungsten Mine is now inactive. 
Map 1

15. Cronese. Mc; Miocene; Barstovian. (Exposures are labelled Muc upper Miocene continental - on the Trona Sheet of the Geologic Map of California.)

The sediments, referred to the Barstow Formation, comprise relatively thin, $\left(100^{\prime}-200^{\prime}\right)$, slightly dipping succession of variegated, generalIy fine-grained tuffaceous deposits and interbedded lapilli tuff that unconformably overlies pre-Tertiary gnessoid granite, and is overlain by alluvium exposures which occur in an east-west trending valley that extends from the powerl ine road about 6 miles west of the northern tip of West Cronese Lake.

Fossils.-- Relatively sparse but important fossil mammals probably represent the youngest Barstovian-age sample in the Mojave Desert; they show a relatively evolved Merychippus and are associated with tuffs dated radiometricalIy at 12.3 m.y. Merychippus intermontanus.

References.-- Trona Sheet; P-26; UC Riverside Department of Earth Sciences Vertebrate fossil locality files.

Institutions with major collections.-- U.S. Geological Survey, Denver; Department of Earth Sciences, University of California, Riverside; Nat. Hist. Mus.

Values.-- Research; RI. This sequence badly needs to be adequately mapped, described, and prospected for more fossils. It may represent the northeastern-most occurrence of the Bartow Formation in the Mojave Desert, and the young potassium-argon dates, associated with the fossils, provide the best evidence of the young period of sedimentation. The fossils are evolutionaily advanced, and may represent a level just prior to that of the next age (Clarendonian).

Educational; El. Students and professionals. See above. Recreationa1; RO. Exposures are limited; part are on a military reservation.

Industrial; I2. Nothing significant occurs here. Two smal1 inactive (?gold) claims occur 4 miles south. 
Map 1

16. Alvord Mountain. Mc; Miocene; Hemingfordian and Barstovian. (Exposures are labelled Muc - upper Miocene nonmarine - on the Trona Sheet of the Geologic Map of California.)

A relatively thick sequence of mainly tuffaceous sediment, interbedded with tuffs and basalt flows, is exposed in a broad anticlinal structure in the valley drained by Spanish Canyon and its tributaries, on the east flank of Alvord Mountain. The succession comprises the following units from oldest to youngest: Clews Fanglomerate; Alvord Peak Basalt; Spanish Canyon Formation; Barstow Formation; Granitic Fanglomerate; and a few less extensive sedimentary and volcanic units.

The main fossil bearing unit, thus far, is the Barstow Formation, but at least the Clews Fanglomerate and Spanish Canyon formations should not be ruled out as possible producers of fossils. The Barstow Formation has been divided into three parts - pebble conglomerate and sardstone, with the lower unit being som-what the coarser grained, and thicker (1000' versus about 500'). The middle unit is thin (about 100' thick or less) and is composed of two to three lapilli tuffs dated at 13.3 and 13.4 m.y. Fossils.-- Most of the fossils occur in and within a few feet stratigraphically above and below the middle unit; these are of Barstovian age. A few others, important for their Hemingfordian age, occur $400-500^{\prime}$ stratigraphically below the middle unit. The succession here is especially important in that it corroborates the biostratigraphic and evolutionary sequence seen in the Barstow Formation of the Mud Hills, although parts of the succession may be somewhat younger age than in the Alvord Mountain district. This problem is still being investigated. The Alvord exposures are quite important and should be preserved. Merychippus carrizoensis, Merychyus 
(Metoreodon) relictus, Brachypsal is cf. pachycephalus, Merychippus stylodontus, Merycodus, Brachycrus buwaldi. Protolabis barstowensis.

References.-- Trona Sheet; P-26, P-84.

Institutions with major collections. -- Department of Earth Sciences, University of California, Riverside; U.S. Geological Survey, Denver; Museum of Paleontology, University of California, Berkeley; San Bernardino County Museum, Redlands; R.M. Alf Museum, Webb School, Claremont CA.

Values.-- Research; R1. This is an extremely important area, not only for the collection of fossils known to occur there. The deposits need to be studied from the sedimentological viewpoint because they can be related to the shape of the basin in which they were deposited, which in turn can be used to interpret the possiblity of a former connection with either the cronese area or with the Yermo Hills area, and to thereby aid in deciding whether or not the name Barstow Formation should be used for the A7vord deposits. Educationa 1; E1. Students and professionals, reasons

given above.

Recreational; RO. Little except for browsing around propect pits, and looking for semi-precious stones. Alvord Mine, to the west, once produced gold but is no longer operational.

Industrial; !2. See above. 
Map 1

17. Mojave Valley. Qal; Alluvium; Ranchiabrean.

Series of sites along bluffs that overlook the Mojave River, in gravel, sandstone, and siltstone. Not all specimens collected. Bluffs occur from Daggett-Yermo area eastward to Camp Cady.

Fossils.-- Isolated remains of mammals. Shows that fossils do occur in these Mojave River sediments, and commercial excavations done there should be preseeded by a survey. Marmuthus, Camelops.

References.-- San Bernardino Sheet; 'T-18; San Bernardino County Museum locality reference 1.76.3-9. The remains probably occur in deposits that are part of the overal1 Manix Lake bed succession, which is more extensively displayed to the east.

Institutions with major collections.-- San Bernardino County Museum, Redlands CA.

Values..- Research; R2. Until better developed. May be shown to be part of succession that was deposited in and around Manix Lake.

Educationa 1; E2. Students and professionals, see above. Recreational; RO. Little of redeeming value in these Mojave River Bluffs.

Industrial; I1. At least the western end of the area is apparently being developed as a site for solar power facility. 
Map 1

18. Manix-Afton Canyon. Q1; Qs; Quaternary; Rancholabrean.

The Manix Lake Beds consist of a succession of fine-grained, mostly drab colored lacustrine sediments, interbedded with tufa and tuffs. These sediments grade lateral7y - mostly to the south and southeast into coarsergrained marginal, fluvial facies. The sediments variously unconformably overlie Tertiary (mainly Miocene) sedimentary and volcanic rock, and preTertiary plutonic and metavolcanic rock. The Manix beds are unconformably overlain by alluvium, and are cut by the Mojave River and its tributaries that flow into Afton Canyon. In the Pleistocene, when full, the lake extended westward into the Mojave Valley and northward into what is now Coyote Lake. Unpublished information suggest that some tuffs near the base of the succession correlate with those in the Tecopa and Ventura Basin areas, having an age of somewhat more than 1 million years (see area 3). Radiocarbon dates from higher in the section are as young as about'19,000 years.

Fossils.-- This is one of the few well studied Rancholabrean-aged fossil assemblages in the Mojave Desert region, even though much of the information is still unpublished. Fossils are sparse, and usually fragmentary; their scarcity indicates that the area should be treated with care. Nothrotherium shastense, Mammuthus, Lepus, Canis dirus, ‥ latrans?, Smilodon californicus, Fel is (Punia) atrox, Camelops minidokae, Camelops, Hemiauchenia stevensi?, Antilocapra, Bison antiqus, Equus corversidens, Equus.

References.-- Trona and San Bernardino Sheets; P-4, P-19, P-23, P-53, $T-5, T-18, T 41$.

Institutions with major collections.-- Natural History Museum, Los Angeles; Department of Earth Sciences, University of California, Riverside; San Bernardino County Nuseum, Redlands; Museum of Paleontology, University of California, Berkeley. 
Values.-- Research; R1. The area sheds important information on the Pleistocene life of this part of the Mojave Desert; the correlations suggested on the basis of tuffs indicate that additional work could put together a succession of fossils that would span much of the Irvingtonian and Rancholabrean Land Mammal Ages. The potential for developing a magnetic stratigraphy has not been realized.

Educational; El. Mainly for students and professionals because of the comments made above. A display on the site has been constructed in the Department of Earth Sciences, University of California, Riverside.

Recreational; RI. The area, particulariy around Afton Canyon Campground, is well attended by campers and ORV's. Indiscriminate ORV use away from the campground area and the adjacent ATSF Railroad tracks should be discouraged.

Industrial; I2. 
Niap 1

19. Cady Mountains; Mc; Miocene; Arikareean and Hemingfordian.

These mountains comprise a relatively broad sprawling range south of Afton Canyon. The area is geologically as well as scenically attractive. As is the case in many of the ranges of the Mojave, there is a core of preTertiary plutonic basement rock overlain by a succession of largely volcanic, then volcanic and sedimentary, rocks that have been folded and faulted and are of roughly Miocene age. These are overlain unconformably by less extensive usually coarser-grained deposits of approximately Pliocene age, and along with some Quaternary fan deposits, all of which are finally cut by the present streams, whose valleys are filled with alluvium.

The fossiliferous section in this case is of Miocene age, and consists of interbedded fluviatile clastic and tuffaceous sedinents that are locally quite coarse-grained, and variously reflect derivation from near the core of the present range, or from the flanks of adjacent ranges; such as Cave Mountain, to the north. The deposits have been designated as the Hector Formation, first described from the southwestern portion of the area. There the rocks appear to be coarse- to fine-grained alluvial deposits, interbedded with tuffs and a basalt flow, with the total thickness being on the order of 1500'. To the north, there is a fairly thick (300') pre-basaltic sequence of largely fine-grained tuffaceous material, which includes tuffs dated at about 22 m.y. These beds are followed upward by a basalt, dated at about 19 m.y., and then by a sequence that is generally coarser-grained in the south and southwest, but which becomes finer-grained and of a more lacustrine character to the north. This unit (about $300^{\prime}$ thick) is overlain by an ignimbrite (welded tuff) dated at about 17 m.y., and above this is a tuffaceous, fluviatile squence about 400' thick. Farther north, near Afton Canyon, the sequence is 


\section{c -34}

Map 1

19. Cady Mountains, cont'd.

essentially that from the ignimbrite downward, and at least three units of basalt are present. One of these has been dated at $21 \mathrm{~m} . \mathrm{y}$.

Fossils.-- In the south, fossils of late Arikareean Merychyus calaminthus and Stenomylus hitchcocki) and early Hemingfordian (Michaenia agatensis, Promartes, Daphoenodon, Phenacocoelus, Protolabis) age are separated by a tuff dated at 21.0 m.y. This is one of the best calibrations of the boundary between these mammal ages currently known.

To the north, fossils are mainly of Hemingfordian age, al though one specimen of Merychyus Calaminthus is present in a pre-basaltic part of the sequence (basalt dated at about $19 \mathrm{m.y}$. ). In the post-basaltic part of the column, sparse fossils may be referable to Aletomeryx, similar to that of the Boron fauna ( $p$. ). Fossiliferous units about $200^{\prime}$ above the ignimbrite appears to be of late Hemingfordian age: Merychippus carrizoensis, Anchitheriomys, Diceratherium, Tomarctus hippophagus, Proheteromys sulculus, Miolabis tenuis, Aepycamelus, and Merycodus.

This is becoming one of the most important single areas in the Mojave Desert for biostratigraphy and geologic history because studies now on-going will result in a physical stratigraphic framework with which the southern and northern successions can be related. It will provide one of the best single reference areas for the late Arikaereean to late Hemingfordian interval in California, and will form a secure base with which to evaluate the geological history of this part of the Mojave Desert.

Reference.--San Bernardino Sheet; P-54; P-70, P-71, P-94, P-95, P-99; $T-46, T-47$.

Institution with major collection.--U.S. Geological Survey, Menlo Park; Department of Earth Sciences, University of California, Riverside. 
Map 1

13. Cady Mountains, cont'd.

Values.--Research; RI. See above. Research is ongoing.

Educationa $7 ; E 1$. Students and professionals, see above.

Recreationa 7 RO. Area is adjacent to Afton Canyon which provides recreation in that campground. ORV traffic is normally iimited to areas adjacent to the railroad tracks on the north, powerline roads to the south and east, and certain trails to the west. Rock hound activity focuses on semiprecious stones, mainly in the west.

Industrial; I2 $^{2}$. Low potential. Various mines and claims have been opened or worked but none are now producing except one operation located just north of Afton Canyon.

NOTE: Area includes CRUCERO Pleistocene beds to northeast; Sparse remains of fossil mammals in Quaternary (Rancholabrean) sediments; Only collections are in Natural History Museum, Los Angelés (loc. 1208. All values are of relatively low rank (See 20, p. 35A). 
Map 1

20. Crucero. Qc; Quaternary; Rancholabrean

The sediments are Quaternary conglomerates and sandstones in the SE 1/4, NW 1/4, sec. 26, T. 11 N., R. 7 E., about 3 miles southwest of Crucero. Fossils.--Sparse remains or larger mamals of Rancholabrean age. Reference.--Trona Sheet; Records of Natural History Museum, Los Angeles, no. 1208 .

Insititution with major collection.--See Reference.

Values.--Research, R2. This is based on the sparse nature of the specimens. Additional collections could result in a higher rating. Educational, E2. Reasons same as above. Recreational, RO. Low potential. Area is frequented by ORV's. Industrial, I2. Low potential. 
Map 1

21. Daggett Ridge. Mc; Miocene; Hemingfordian.

These exposures occur in and around the valley occupied by the powerline road about four miles southwest of Daggett, and consist of a few hundred feet of fine-grained varicolored sandstone and siltstone, and a thin bed of gray sandstone lower in the section that produces a hash of bone chips. The sediments unconformably overlie older sedimentary and volcanic rocks, and are capped by a thin unit of freshwater limestone. The limestone is thought to be of Pliocene age. It is covered unconformably, by alluvium, and the whole sedimentary section unconformably overlies Mesozoic plutonic rock.

Fossils.-- These are sparse, and pertain to small camels, a cervoid, and a horse, presumably a parahippine. The remains are apparently of about middie Hemingfordian age, and as such could contribute importantly to an understanding of the generally poorly known faunas of this age in the Mojave. The area is important for this reason, even though the fossils are usually so badly broken up.

Reference.--San Bernardino Sheet; P-90; I-2, I-5.

Institution with major collection.--Natural History Museum, Los Angeles;

Department of Earth Sciences, University of California, Riverside.

Values.--Research; R2. Potential significance is high, but experience has shown that chance for success is not great.

Educational; E2. Low potential, except for student work. Recreational; RO. Little value.

Industrial; I2. Low. See reference P-90. 
Map 1

22. Calico Mountains. Mc; Miocene; Barstovian

This range rises east of Barstow, and has been the location of former silver and colemanite mines, none of which are now operative. The Calico Ghost Town is a current tourist attraction. The mountains contain a folded and faulted succession of Tertiary volcanic and sedimentary rocks that rest upon a pre-Tertiary plutonic and metasedimentary basement. The Tertiary section is on the order of 10,000 feet thick, and is intruded by dikes and plugs of rhyolite and andesite that are probably of Pliocene age.

The Tertiary sedimentary succession is comparable to that of the Mud Hilis (see 23) and will not be extensively treated here. The Jackhammer, Pickhandle, and Barstow formations all occur, with the first two being better represented than in the Mud Hills. The main depocenters of the Jackhammer and Pickhandle formations appear to be in the Calico Mts. region, where the Jackhammer is about $700^{\prime}$ thick, and the Pickhandle about 5,000' thick. The Barstow Formation is thinner than in the Mud Hills, being on the order of $3,000^{\prime}$ thick in the Calico Mountains.

Fossils.--Fossils are generally sparser in the Calico Mountains than in the Mud Hills, and appear to represent only the upper faunal division, Merychippus intermonatanus, at least, has been recorded. Insect-bearing nodules also occur.

Reference.--Trona and San Bernardino Sheets; P-47, P-47, P-48, P-49, P-89, P-90; I-7, I-7; T-22.

Institution with major collection.--U.S. Geological Survey, Denver. 
Map 1

22. Calico Mountains, cont'd.

Values.--Research; R2. The area is one of definite potential, but much of it seems to be located on private land, access being limited. An important aim would be to study the stratigraphy of the Barstow. Formation here to assess the relationships between these deposits and those in the Mud Hilis, on the one hand, and with the sediments of the Yermo Hills, on the other.

Educational; E2. Mainiy because of access problems.

Recreational; RT. Mainly centered on the Calico Ghost Town, a commercial enterprise.

Industrial; I2. Low potential, Mining has been extinct for nearly 80 years. 
Map 1

23. Mud Hills - Barstow Syncline. Mc; Miocene; Hemingfordian and Barstovian (exposures are labeled Muc and Mmc on the Trona Sheet)

Scenically spectacular outcrops of the Jackhammer, Pickhandle and Barstow Formations occur in a synclinally folded succession about 8 miles north of Barstow, California. The sequence unconformably overlies pre-Tertiary plutonic and metamorphic rock and is unconformably overlain by alluvium. The Jackhammer Formation is about $100^{\prime}$ thick in the Mud Hilis, is exposed only on the north flank of the syncline, and is comprised of arkosic pinkish gray sandstone, with few pebbles and cobble of quartz monznonite and quartzite, interbedded with minor beds of tuff, amygdaloidal basalt and limestone. This formation is the basal unit of the Tertiary succession in the area, and was originally named for rocks in Jackhammer Gap in the northwestern Calico Mountains.

The Pickhandle Formation, named for Pickhandle Pass in the Calico Mountains, conformably overlies the Jackhammer beds, and is largely a unit of pyroclastic rocks about 3,000 ' thick. The rocks are mainly light-colored rhyolitic, lithic and lapilli tuff, with local lenticular units of agglomerate, granitic breccia, conglomerate, sandstone, claystone, and limestone.

The Barstow Formation, named for the Barstow fossil beds, consists of about 6,000 ' of lacustrine and fluviatile sediments, interbedded with beds of tuff. The unit unconformably overlies the Pickhandle Formation in the Mud Hills, and contains a basal member (informal name) of conglomerate, sedimentary breccia and mega-breccia derived from sources to the north or northeast (Paradise Mountain quartz monzonite and Jackhammer and/or Pickhandle volcanic rocks) or south and southeast (Mesozoic granitic rock, Tertiary volcanic rock, and ?Precambrian Waterman Gneiss). 
Map 1

23. Mud Hills - Barstow Syncline, cont'd.

The basal unit is unconformably overlain by the Own Canyon member (informal name), yellow green and pale green, calcareous sandstone, siltstone, and claystone with some limestone, interbedded tuff, and conglomerate up to $3000^{\prime}$ thick. To the west this unit interfingers with the Coon Canyon member (informal name), of pale brown to yellow brown coarse to fine grained sandstone probably derived from the south or southeast. This unit does not occur on the north limb ofthe syncline.

The Skyline Member (informal name) consists of brown claystone and green claystone beds about $400^{\prime}$ thick which has at its base the white, vitric, Skyline Tuff, spectacularly exposed in Rainbow Basin. Like the Owl Canyon Member, the Skyline Member interfingers to the west with the Coon Canyon Member. A coarse-grained crystalline tuff occurs $30^{\prime}$ to $90^{\prime}$ above the Skyline Tuff and is dated at about $15.1 \mathrm{~m} . \mathrm{y}$.

The Hemicyon Member (informal name) contains a sequence of tuffaceous, generally greenish-colored deposits up to $400^{\prime}$ thick. The Unit occurs onily in the western half of the syncline, interfingers westward with the coon Canyon Member, and grades upward into the Carnivore Canyon Member. The base of the unit is defined by the Hemicyon Tuff, a gray, fine-grained silty vitric tuff, dated at about 13 m.y. Another unit, known as the Lapilli Sandstone, about 100' above the basal tuff, has been dated at 13.2 and 13.4 m.y.

The Carnivore Canyon Member is the uppermost unit of the Barstow Formation, $300^{\prime}$ thick, composed of coarse-grained pale brown to yellow brown beds of sandstone interbedded with green tuffaceous siltstone.

Fossils.--The Barstovian Land Mammal Age was based on the fossiliferous beds of the Barstow Formation which has been one of the most productive rock 
Map 1

23. Mud Hills - Barstow Syncline, cont'd, units of the Mojave Desert region. In spite of this, only a few reports have been published on these fossils and the rocks that contain them. There is still a lot to be done.

Work that has been published shows that there are three major faunal divisions in the Barstow Formation. The lowest of these occurs near the top of the Basal Member and contains Merychippus carrizo ensis (M. tehachapiensis), and Merychyus (Metoreodon). The assemblage is of late Hemingfordian age and is better represented in the Yermo Hills, to the east. There, $\underline{M}$. carrizoensis ranges upward to coexist with $\underline{M}$. stylodontus.

The middle faunal division included $\underline{M}$. stylodontus, Brachycrus buwaldi, Rakomeryx, Merriamoceros, Hesperhys, Aepycamelus, Euoplocyon, Amphicyon cf. ingens, and the earliest North American record of Hemicyon.

The upper faunal division, which can be used as the type Barstovian fauna,

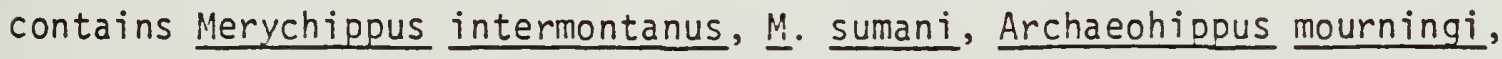
Megahippus McKennai, Paramoceros, Meryceros, Mediochoerus and the first appearance of Aelurodon and Gomphoterium.

Recently work by Lindsay $(P-27)$ has shown that it is possible to propose a finer scale subdivision of these rocks based on small mammals, and is an example of the kinds of results that can be achieved even now with careful, detailed work. The deposits are still of prime research value.

Reference.-.Trona Sheet; P-1, P-13, P-22, P-24, P-25, P-26, P-27, P-28, P-29, P-35, P-39, P-40, P-41, P-51, P-53, P-59, P-78, P-89; T-21, T-32; I-1.

Institution with major collection.--American Museum of Natural History, New York; Museum of Paleontology, University of California, Berkeley; Department of Earth Sciences, University of California, Riverside; Natural History Museum, Los Angeles; San Bernardino County Museum, Redlands; R. M. Alf Museum, Webb School, Claremont, CA. 
Map 1

23. Mud Hills - Barstow Syncline, cont'd.

Values.--Research; R1. See above.

Educátional; El. Students and professionals.

Recreationa 1; RT. Rainbow Basin Loop and the OWT Canyon area are of good recreational value because of spectacular scenery. The area is now maintained as a San Bernardino County Park.

Industrial; I2. Low välue. Coolgardie Camp, north of the fossil beds contains sporadically worked gold. diggings. Strontianite claims occur in the OWl Canyon area, but are not now producing. Traces of uranium have been found in bones in the southern part of the Mud Hills, and there is a certain amount of rock hound activity for semi-precious stones, 
Map 1

24. Black Mountain-Gravel Hills. Mc; Miocene; Barstovian.

This district contains a reasonably scenic, rolling small-scale badlands topography entered mainly from the south, via Black Canyon, to the north of Harper Lake. Most of the southeastern and eastern part of the area is capped by the late Quaternary Black Mountain Basalt.

A reasonably thick succession of volcanic and volcaniclastic sedimentary rock comprise most of the Tertiary section. These beds unconformably overlie pre-Tertiary plutonic rock, and are unconformably overlain by the basalt, mentioned above, or by alluvium. The Tertiary section is tilted and faulted, and locally (in Black Canyon and areas northwest) gently folded.

Most of the Tertiary section consists of the Barstaw Formation, but locally it is conformably underlain by the Pickhandle Formation. The latter is mainly a pyroclastic unit about $150^{\prime}$ thick, composed of tuff and tuff breccia with minor beds of sedimentary rock, locally interbedded with the Opal Mountain Volcanics. The latter, a sequence of quartz latite flows, apparently was emplaced from local vents, the tuffs of the Pickhandle Formation recording explosive events.

The Barstow Formation is the most extensive Tertiary unit in the Gravel Hills. It is thickest $\left(4,500^{\prime}\right)$ to the west and thins to the northeast. The lower part consists largely of lacustrine clay and shale, with a gradational lower contact with the Pickhandle Formation. Above the lake beds grade upward into sandstone, then northward and northeastward to volcanic fanglomerate. In the vicinity of Black Canyon, the sandstone unit is interbedded with a flow of basalt, and beds of tuff. Upward and to the northwest the sandstone unit grades into a fanglomerate of granitic debris, which also interfingers eastward with the volcanic fanglomerate described above. The two fanglomeratic 
Map 1

24. Gravel Hills-Black Mountain, cont'd.

facies reflect different areas of origin, granitic largely to the west or southwest, volcanic largely to the north or northeast, toward the main locus of the older Opal Mountain Volcanics.

Fossils.--A relatively meagre collection of fossils has been recovered from the tuffaceous sandstone unit in the vicinity of Black Canyon. Merychippine horses indicate a Barstovian age. Merycodonts also occur. This area needs more work. The stratigraphiv is only partly documented, and the correlation of these beds with the type Barstow Formation is only partly accomplished. Merychippus, Merycodus.

Reference.--Trona Sheet; P-89; P-90.

Institution with major collection.--U.S. Geological Survey, Denver; Department of Earth Sciences, University of California, Riverside.

Values.--Research; Rì. See above.

Educational; El. Students and professionals, see above.

Recreational; RI. At least at mouth of Black Canyon petrogiyphs are known; the Black Canyon area is also scenic. This is also the area where fossils are known to occur. Care in ORV use is warranted. The Opal Mountain area, to the northeast, encourages much rock-hound activity.

Industrial; 12. To the west, in Fremont Peak, are numerous gold claims and prospects. Activity is minimal. To the northwest of the sedimentary exposures, feldspar is mined in the White Butte mine. Perlite is prospected and mined intermittently in areas north of the sedirients, but the operations are small. 
Map 1

25. Boron. Qual; Alluvium; Hemingfordian

The fossil-bearing deposits occur in the open pit mine of U.S. Borax and Chemical Corporation, and thus is below the alluvial cover. This explains the seemingly contradictory geological notations, given above.

The workings are located a few miles north of Boron, California, and are developed in the upper part of the Tropico Group. The borate and fossit producing beds are buff to tan to dark reddish-brown clay and micaceous siltstone, and coarser grained cross-bedded, light brown to yellowish-white arkosic sandstone and pebble conglomerate, locally tuffaceous. These beds which are about $250^{\prime}$ thick, rest conformably on the Saddleback Basalt, which has been dated at 19.8 m.y. Above the clays and siltstones, are about $200^{\prime}$ of arkosic sandstone, and $300^{\prime}$ of granitic conglomerate.

Fossils.--The Boron fauna is largely unpublished, but is considered to be of about medial Hemingfordian age. Mammals recorded are Oreolagus? Hypolagus?, Protospermophilus, Trogomys cf. rupinimenthae, Merychyus (two unnamed species), paratylopus?, Oxydactylus?, cf. Hesperocamelus, and a new species of Aletomeryx. This is the only well known medial Hemingfordian fauna from the Mojave Desert.

Reference.--Trona Sheet; P-65, P-91, P-92, P-93, P-99, P-100; I-1, I-10. Institution with major collection.--Department of Earth Sciences, University of California, Riverside.

Values.--Research; R2. Even though the area is important, access is very limited.

Educational; E2. Access is very limited. - Recreational; RO. None. 
Map 1

25. Boron, cont'd.

Industrial; II. U.S. Borax and Chemical Corporation is currently working the area. 
Map 1

26. Horned Toad Hills. Pc; Pliocene; Hemphillian.

(Exposures labelled Pmlc - middle and/or lower Pliocene, nonmarine, on the Bakersfield Sheet.)

The area is located a few miles northwest of Mojave, Calif., in gently rolling hills that rise southeast of the Garlock Fault. The beds, the Horned Toad Formation, unconformably overlie pre-Tertiary plutonic rock, and gently dip to the southeast. Locally, they are folded in to a shallow anticline and syncline. The succession, about 1000' thick, consists of a lower section of mainly buff to reddish-gray arkosic conglomeratic sandstone, pebbly sandstone, and siltstone. A middle unit is about 100' thick and composed of interbedded greenish-gray shale, green sandstone, some tuffaceous and white marly limestone. An upper member of about the same thickness consists of greenish-gray gypsiferous claystone.

Fossils.--The fossils come from the middle tuffaceous unit. So far the . tuff is undated. Both large and small mammals have been recovered. The fauna is largely unstudied, but preliminary comparisons indicate affinities with late Hemphillian faunas of northern California, Texas, and Florida, an interesting zoogeographic combination. This is the best represented Hemphillianaged fauna from southern California, and additional collecting as well as detailed stratigraphic work still needs to be accomplished. ?Meotomodon, Peromyscus, Perognathoides, Hypolaqus, Osteoborus, ?Fel is, Teleoceras, Dinohippus cf. interpolatus, Astrohippus?, camels, ?deer, peccary, Rhynchotherium edensis, Pliomastodon.

References.--Bakersfield Sheet; Department of Earth Sciences, University of California, Riverside, locality files; also Museum of Paleontology, University of California, Berkeley; I-1; P-91. Natural History Museum, Los Angeles. 
Map 1

26. Horned Toad Hills, cont'd.

Values.--Research; RT. See above.

Educationar; El. Students and professionals, see above.

Recreational; RO. Some ORV activity occurs. In view of the research potential, this should be discouraged. A set of jaws and tusks of a large, extinct proboscidean (mastodont) is on display at UCR.

Industrial; I2. Little potential.

Institution with major collection.- See References. 
Map 1

27. Barrel Springs Road. Qc; Quaternary; Rancholabrean,

The fossil localities occur on the north side of a northwest trending ridge, just south of the Nadeau fault in sec. 18, T. $5 \mathrm{~N},, \mathrm{R}, 11 \mathrm{~W}$. , in light grayish-green and tan sandstone and pebbly sandstone about 4' below a claiche layer in the uppermost Harold Formation, within a few 10's of feet below its stratigraphic top.

Fossils..- There are large and small mammals, the latter comprise the only small mammal fauna of Rancholabrean age in the Mojave Desert. It is currently unstudied, but should reveal significant information as to the climate of the time, and will be a valuable comparative fauna relative to those known from the Anza-Borrego area. Small mammal faunas of almost any age are rare in California paleontology, in contrast to the much better record of the Plain states. Any small mammal site in California deserves preservation. This one is additionally important in refining the age of the Harold Formation which is cut by branches of the San Andreas fault, and bears importantly on the tectonic history of this region. Shrew, rabbit, Peromyscus, ?Perognathus, squirrel.

References.--Los Angeles Sheet; Department of Earth Sciences, University of California, Riverside, locality record; P-96. Natural History Museum, Los Ange] Institution with major collection.--Department of Earth Sciences, University of California, Riverside. Area on Map I includes Nat. Hist. Mus. loc 45$]$ Values.--Research; RT. See above.

Educational; RT. Students and professionals, see above.

Recreational; RO. Area is barren and unexciting. Industrial; I2. Low potential. 
Map 1

28. Valyermo. Mc; Miocene; Ciarendonian and Hemphillian.

The COCA just extends into the northern part of the exposures of the type Punchbowl Formation, which consists of about 4,000' of arkosic conglomeratic sandstone, and minor siltstone beds that have been deformed into the spectacular Devil's Punchbowl. Most of the area is part of Los Angeles County Park; the rest is private property, but fossils have been found in these deposits which are important for indicating their age. Also, stratigraphic studies have been performed and provide valuable evidence with which to compare these rocks, both in lithology and age, with others in Cajon Valley to the southeast. The two sets of rocks have been proposed as once having been juxtaposed, and since separated by 20-30 miles of right lateral slip on the San Andreas fault. Recently, both lithologic and age correlations have been scrutinized ( $P-83$; which see for other pertinent references, including theses), with the result that the correlations are not so secure as once thought.

Fossils.--Most of the fossils have come from the area of the county park, but some could be found almost anywhere. Any are very important. Pliohippus tehonensis; Procamelus, Neohipparion, Pliohippus, Plioceros, Plionictis, Osteoborus cf. $\underline{0}$. cyonoides.

Reference.--San Bernardino Sheet; P-88, P-87; I-1; T-6.

Institution with major collection.--Department of Earth Sciences, University of California, Riverside; Natural History Museum, Los Angeles. Values.--Research; RT. See above; also of continuing importance for stratigraphical and sedimentological studies.

Educational; El. See above, student and professional. 
Map 1

28. Valyermo, cont'd.

Recreational; RT. The area is very scenic; many persons visit the county park, and camp in campsites in the general area.

Industrial; I2. Little value. 
$\operatorname{Map} 1$

29. Eastern Cajon Valley. PC; Pliocene; ?Blancan and younger. QC; Quaternary; Rancholabrean.

The Tertiary succession of Cajon Valley is only partly included in the CDCA. The part that is incorporates exposures of the Crowder and Harold Formations, and the Shoemaker Gravel. This is a generally coarse-grained sequence ofnonmarine, fluviatile, conglomeratic sandstone, and sandstone, exposed in the so-called in-face bluffs, and in valleys to the east. The Crowder generally contains a greater variety of rock types than the sediments of the Harold Formation that gradationally overlie it. The Harold is also gradationally overlain by the coarser-grained Shoemaker Gravel that contains abundant clasts of Pelona Schist and other rocks derived from the San Gabriel Mountains to the southwest. The total succession has important bearing on the upl ift history of the San Bernardino and San Gabriel Mountains, as well as upon the slip story of the San Andreas fault.

Fossils.--Only sparse, inconclusive, fossils have yet been found in the Crowder Formation. None have been found yet here in the Harold or Shoemaker. The Harold bears fossils of Rancholabrean age in the vicinity of Palmdale; the Shoemaker contains Rancholabrean fossils in gravel pits near Victorville. Reference.--San Bernardino Sheet; P-87, P-88; I-1; Department of Earth Sciences, University of California, Riverside, locality files.

Institution with major collection.--Department of Earth Sciences, University of California, Riverside.

Values.--Research; RI. See above. The area has high research potential for not only fossil collection, but also stratigraphical and sedimentological studies.

Educational; El. Students and professionals, see above. 


$$
\text { C }-52
$$

Map 1

29. Eastern Cajon Valley, cont'd.

Recreationa $;$ RO. Little value.

Industrial; I2. Little, possibly gravel pits. 
Map 1

30. Victorville - Mojave Rivel. Qc; Quaternary; Rancholabrean.

A number of sites occur in the relatively coarse-grained fluviatile sandstone and gravel beds, 10cally $200^{\prime}$ or so feet thick, that are best exposed in gravel pits near Victorville, but also extend along the banks of the Mojave River to Barstow. The deposits are important in that they relate to the uplift of the San Gabriel Mountains to the south, and to the history of the Mojave River. To date they are pooriy studied. Near Victorville they have been referred to as the Shoemaker Gravel.

Fossils.--Best fossils have been obtained from gravel pits and other exposures around Victorville, but others are known from exposures to the north. Host are of large mammals. Equus.

Reference.--San Bernardino Sheet; locality references of San Bernardino County Museum; I-1; also Natural History Museum, Los Angeles.

Institution with major collections.--Natural History Museum, Los Angeles; San Bernardino County Huseum, Redlands .

Values.--Research; R2. The fossils are generally sparse and until a major site can be developed, immediate research potential is low. Remains are important, however, in dating the age of active shedding of debris from the emergent San Gabriel Hountains, and documenting the activity of the Mojave River.

Educationa 1; E2. Corresponds to research potential. Recreational; RO. Little major recreational value. Industrial; Il. Locally, for gravel pits. 
Map 1

31. Cushenbury. TC; Tertiary; Blancan.

These beds are referred to as the 01d Woman Sandstone of Shreve $(P-86)$. They comprise a succession 200'-1000' thick, composed of massive reddish-buff to red-brown conglomeratic arkose with a matrix of uncemented, poorly sorted, coarse-grained, angular fragments of quartz, feldspar, hornblende, etc., that support subangular to subrounded pebbles of andesite, gneiss, quartzite, and minor other types. All lithologies are found in the San Bernardino Mountains, to the south, except for the volcanic rocks. Woodburne $(p-87)$ reports ( $p .83)$ on basalt outcrops in Santa Ana Canyon to the south, dated at 6.2 m.y. Other volcanic rocks, near Pioneer Town have been dated at $7.3 \mathrm{~m} . y$. Together, these volcanic rocks suggest that activity (and extension; ?=uplift) occurred in the San Bernardino Mountains about that time. The old Woman Sandstone is the oldest Tertiary deposit to be derived from the San Bernardino Mountains (on the north side, at least) and reflects uplift of the ranges. Dating these sediments would provide important evidence as to the age of that uplift.

Fossils.--A small, but important, and growing collection of small mamal fossils has been collected by personnel at UCR. These appear to be of Blancan (probably late Blancan; see Figure B-2) age, and suggest that the San Bernardino Mountains began shedding debris to the north about 2 m.y. ago. These fossils provide the ONLY evidence for the age of that uplift. Pliogeomys, ? Citellys, Hypolagus?

Reference.--San Bernardino Sheet; P-86, P-87.

Institution with major collection.--Department of Earth Sciences, University of California, Riverside.

Values.--Research; RI. See above.

Educational, El. Students and professionals. See above narrative. 
Map 1

31. Cushenbury, cont'd.

Recreationa?; RO. Very little. Some rock-hound and minor ORV activity occurs.

Industrial; I2. Kaiser Cement mines limestone along the west side of Cushenbury Canyon, but nothing else of importance occurs in the area. 


\section{C -56}

Map 1

32. Twenty-nine Palms. Qc; Quaternary; Rancholabrean.

This is an unnamed succession of largely northeast-dippling fluviatile and lacustrine sediments, and interbedded tuff a few miles east of the main north road from Twenty-nine Palms. The exposures are relatively isolated patches of older sediment, surrounded by younger alluvium.

Fossils.--Thus far a meagre, but interesting fauna of Rancholabrean large mammals has been collected. Equus, Odocoileus, Tanupolama?, Hemiauchenia?, Bison, Ovis, Breameryx? Geopherus, Nothrotheriops? Taxidea, Camelops.

Reference. --San Bernardino Sheet; P-84; Locolality records of San Bernardino County Museum; 1-86-1 - 4 .

Institution with major collection.--San Bernardino 'County Museum, Redlands, CA.

Values.--Research; RI. This is a promising area and more fossil and stratigraphic information could bear importantiy on the history of movement on the Mesquite Fault, which intersects the deposits.

Educational; El. Mainly for students and professionals in the area of stratigraphy, tectonic movements.

Recreational; Ro. Nothing of exceptional value.

Industrial; 12.. Some of the gravel may be of commercial value. An abandoned gravel pit is in the area, and some relatively recent bulldozer work has been observed. 
33. Shadow Mountains 1. Qc; Quaternary; Irvingtonian or Rancholabrean. Exposures oflacustrine sediments on eastern flank of Shadow Mountains. Fossils.--Sparse remains of rabbit, Lepus, and other bone fragments. Reference:--Kingman Sheet; San Bernardino County Museum records, 1-6-1. Institution with major collection.--San Bernardino County Museum. Values.--Research; R2. The somewhat low value stems from the fact that littie is known about these deposits. Fossil-bearing areas in the eastern Mojave Desert have not been explored as much as areas to the west, so R2 could easily become R1.

Educational; E2. For same reasons as above; could become El. Recreational; RO. Possibly except for rock hounds looking around abanconed mines in the area.

Industrial; i2. Low potential. 
Map 2

34. Shadow Mountains 2. Tc; Tertiary; possibly Barstovian.

Tertiary sediments on east flank of Shadow Mountains overlain by Paleozoic or pre-Paleozoic thrust plate.

Fossils.--Sparse remains of deer-like form.

Reference.--Kingman Sheet; San Bernardino County Museum reference 1-6-2. Institution with major collection.--San Bernardino County Museum.

Values.--Research; R2. Low value is due mainly to lack of information. The geological setting cculd be quite significant because the fossils could date the sediments and establish a lower limit for the age of thrusting in this area.

Educational; E2. Low value for reasons ștated above.

Recreational; RO. Low; possibly except for rock-hounds looking around the abandoned mines in the area.

Industrial; i2. Low potential. 
Map 2

35. Valley Wells. Q1; Quaternäry; Irvirigtonian.

In the vicinity of Valley Wells, a succession of lacustrine sediments, capped by tufa, is displayed in a smal1-scale badlands topography. Cross bedded quartz sands contain the fossils.

Fossils.--A significant, but difficult to collect, fauna has been obtained, including remains of Camelops, Mammuthus, Equus simplicidens, Equus ?conversidens, Hemiauchenia, and Antilocapra americana.

Reference.--Kingman Sheet; San Bernardino County Museum reference 1-1-1A, $B, C$, and $1-1-12 ; P-23, P-50$.

Institution with major collection.--San Bernardino County Museum. Values.--Research; R1. This area is quite significant. It yields the best quarry sample of Irvingtonian fossits to be found in the Mojave Desert.

Educationa 1; El. For students and professionals; stratigraphy, biostratigraphy, and paleontology.

Recreationa 1; RO. Low potential.

Industriai; 12. A talc grinding mill operates here, processing rock collected mainly from the kingston Range. Area is a few miles north of the Southern Shadow Valley PGRA. 
Map 2

36. Crystal Cave. IP; Paleozoic; Subrecent.

This is a vertical cave on east side of Kokoweef Peak, on its east side, so that the age of the materials bears no relationship to the age of the surrounding rock.

Fossils. - A specimen of a Lynx was recovered.

Reference.--Kingman Sheet; San Bernardino County Museum reference 1-11-14. P-102, P-103.

Institution with major collection.--San Bernardino County Museum.

Values.--Research; R2. Low because of meagre extent of material. The Mountain Pass rare earth district occurs to the north, but access is 1 imited.

Educational; E2. Low, see above.

Recreational; RO. Possible interest to rock hounds; abandoned mines.

Industrial; I2. Low potential at this site; the Mountain Pass rare earth district occurs two miles to the north. 
Map 2

37. Suiphide queen Fissure Fill. epG; Precambrian; Sub-recent?

This is a fissure fill in a bastnaesite ore body. The age of the material bears no relationship to that of the surrounding rock.

Fossils.--Lepus and Sylvilagus, reported but not collected.

Reference.--Kingman Sheet; San Bernardino County Museum reference 1-1-27. P-102, P-108.

Institution with major collection.--None.

Values.--Research; R2. Low potential, limited material. Site is in Mountain Pass rare earth district; access is limited.

Educationa 1; E2. Low, see above.

Recreational; RO. Low, see above; rock hounds may have interest in generai area; abandoned mines.

Industrial; Il. Mountain Pass rare earth district. 
Map 2

38. Ivanpah Mountains. gr; Mesozoic; Rancholabrean.

Material is in a cave, northeast of Kessler Peak, and bears no relation to the age of the surrounding rock.

Fossils.--Canis latrans, Marmota flaviventris, Equus, Lepus Sylvilagus.

Reference.--Kingman Sheet; San Bernardino County Museum reference 1-11-13.

Institution with major collection.--San Bernardino County Museum;

Department of Earth Sciences, University of California, Riverside.

Values.--Research; RT. This is a valuable site in providing a good glimpse of a Rancholabrean fauna in the eastern Mojave Desert, combining large and small mammals.

Education; El. See above, students and professionals.

Recreation; RO. Mainly rock hounds, abandoned mines.

Industrial; I2. Little potential. 
$\operatorname{Map} 2$

39. Northern Piute Valley. Q1; Quaternary; Irvingtonian.

The sites are located in lacustrine sediments east of the Piute Range, northern Piute Vallej.

Fossils.-. This is a meagre but nevertheless important assemblage of Irvingtonian mammals; Microtus cf. californicus, Equus (Dolichohippus) cf. conversidens, Hemiauchenia?, Camelops.

Reference.--Kingman Sheet; San Berrardino County Museum reference 1-28-1 to $4, P-23$.

Institution with major collection.--San Bernardino County Museum.

Values.--Research; RI. This is an important site in and of itself, and because it contributes to the growing evidence that many, if not all of the Quaternary lakes in the Mojave Desert region are of Irvingtonian age.

Educationa 1; El. See above, students and professionals. Recreationa 1; RO; Little value.

Industrial; I2. Low potential. 
Map 2

40. Sands. QC, Qs; Quaternary; Rancholabrean.

There are a series of sites near the ATSF Railroad tracks and the highway, along the southwestern edge of the Devil's Playground, about one mile northwest of Sands Junction (on the railroad line). The fossils occur in brown and dark grayish-green fine-grained lacustrine sandstone, and stiltstone, overlain by a cap of tufa.

Fossils.--Equus, Camelops, Mammuthus, ?Hemiauchenia, and associated lacustrine gastropods.

References.--Kingman Sheet; locality records of San Bernardino County Museum (1-62-1 and 2) and Department of Earth Sciences, University of California, Riverside (RV-7001 to 3$) ; P-23$.

Institution with major collection.--San Bernardino County Museum; Department of Earth Sciences, University of California, Riverside.

Values.--Research; R7. Important Rancholabrean locality, with bearing . on age of lacustrine deposition in Mojave Desert.

Educational; El. See above; students and professionals. Recreational; RO. Low potential possibly ORV activity along railroad tracks.

Industrial; I2. Low potential. 

$\operatorname{Map} 2$

41. Eastern Hackberry Mountains. Tr; Tertiary; Barstovian.

These fossils come from sediments interbedded with a largely extrusive and pyroclastic volcanic succession (Tvp on Kingman Sheet). They indicate that all areas mapped as Tertiary volcanics, Miocene volcanics, etc., have a potential for yielding fossils from interbedded sedimentary units.

Fossils.--Rhinoceros, Plioceras?, Miolabis?

Reference.--Kingman Sheet; San Bernardion County Museum reference $1-26,1 A$.

Institution with major collection.--San Bernardino County Museum.

Values.--Research; R2. The lower designation could be changed to R1, when more material becomes known. This is one of a small number of Barstovian, or possibly Hemingfordian-aged sites in the southeastern Mojave Desert that need much more work.

Educationa; E2. See above. Could easily be raised to El. Recreational; RO. Low potential, except for rock hound activity. Industrial; I2. Low potential. 
Map 2

42. Eastern Sacramento Mountains. Qc; Quaternary; Barstovian.

Conglomeratic beds mapped as QC on Needles Sheet; should be mapped as Tc, because the fossils show that the rocks are of Miocene age.

Fossils.--Fossils recorded, but not in collections, are identified as Merychippus.

Reference.--Needles Sheet; San Bernardino County Museum reference $1-30-1$ and 2 .

Institution with major collection.--None.

Values.--Research; R2. Low potential for now, until more information becomes known.

Educationa 1; E2. See above.

Recreational; RO. Low potential; abandoned mines.

Industrial; I2. Low potential. 
Map 2

43. Little Piute Mountains. TC; Tertiary; Barstovian.

These deposits, mapped as Tc on the Needles Sheet, occur around the flanks of the Little Piute Mountains. Fossils occur in gray green lacustrine sediments.

Fossils.--Reported but not collected, were fragmentary bones of Merychippus. This is another of the poorly known but important sites in the southeastern Mojave Desert, that need further work.

Reference.--Needles Sheet; San Bernardino County Museum reference 1-30-2. Institution with major collection.--None.

Values.--Research; R2. Low potential because of inadequate knowledge. When more becomes known, rating could easily become $R T$.

Educationā1; E2. See above.

Recreationa; RO. Low potential; rock hound prospecting in abandoned mines.

Industrial; I2. Low potential. 
Map 2

44. Indio Hills. Pc?; Pliocene; Irvingtonian. QP; Plio-Pleistocene; Irvingto Q̣c; Quaternary; Irvingtonian and Rancholabrean.

The Indio Hills comprise an elongate, northwest trending series of hills on the northeast side of the Coachella Valley. They are cut by a number of branches of the San Andreas fault zone, and have been uplifted and folded along them. The sedimentary units correspond to the Mecca and Palm Springs formations and the Canebrake and Ocotillo conglomerates in the southeastern part of the hills, to the Willow Hole, Willis Palms, Thousand Palms, and Indio Hills formations to the northwest.

The Willow Hole (informal name) consists of a succession of interbedded conglomerate, sandstone, and siltstone, with minor tuff'and tuff breccia, on the order of $2500^{\prime}$ thick. Locally, monolithologic breccia units interfinger with finer-grained sediments. This formation stratigraphically underlies the Willis Palms Formation (informal), which is lateral equivalent of the marine Imperial Formation. The Willow Hole was formerly (0-104) referred to as the Ocotillo Conglomerate which overlies the Imperial Formation. Based on basement rock types, the Willow Hole appears to have been derived from the north and northwest, and probably is stratigraphically equivalent to the Mecca Formation to the southeast rather than the ocotillo conglomerate.

Fossils.--Sparse remains of Equus (Dolichohippus), and Mammuthus, have been collected, suggesting an Irvingtonian age.

The Willis Palms Formation (informal) conformably overlies the Willow Hole Formation, and is unconformably overlain by the Indio Hills Formation. The Willis Palms is on the order of 100-200' thick, and consists of grayish yellow to locally orange marine siltstone, and contains remains of marine organisms. 
$\operatorname{Map} 2$

44. Indio Hills, cont'd.

The Willis Palms Formation was deposited by a short-lived marine embayment that extended as far north as the vicinity of Whitewater, east of San Gorgonio Pass.

The Thousand Paims Formation (informal) probably corresponds to the Palm Spring Formation (P-104, T-48), probably interfingers at its base with the Willow Hole Formation, and interfingers laterally with the Hillis Palms Formation. To the southeast, the Palm Springs Formation interfingers laterally with the Canebrake Conglomerate. The Thousand Palms is on the order of 1900' thick, and consists of sparse tongues of conglomerate interbedded with light gray to gray or greenish gray sandstone, fine-grained sandstone, and siltstone. No fossils have been found yet, but to the southeast fossils of probable Irvingtonian age have been recovered from the laterally equivalent Palm Springs Formation.

The Indio Hills Formation is the most widely exposed unit in the Indio Hills, and corresponds in part to the Ocotillo Conglomerate (P-104, T-48), and is about $3,000^{\prime}$ thick. The formation consists of gray conglomerate, greenish-brown arkosic sandstone, gray to yellowish-gray siltstone, sandstone, and conglomerate and minor beds of tuff.

Fossils.... Sparse remains of Equus, and ?Mammuthus have been recovered, of probable Rancholabrean age.

Reference.--Santa Ana Sheet; P-104; P-105; T-14; T-34; T-48.

Institution with major collection.--American Museum of Natural History, New York; Department of Earth Sciences, University of California, Riverside. Values.--Research; R2. The relatively low value is given because of the generally sparse nature of the fossils, although the American Museum collections are more extensive. These have not been seen. Even though most of the 
Map 2

44. Indio Hills, cont'd. references to the area are unpublished theses, the research potential is rather good and important because of the proximity of these rocks to branches of the San Andreas fault zone, and the opportunity to use them to evaluate amount and timing or slip on those branches. The various beds of tuff in the section should be sampled for dating.

Educational; E2. Same reasons as for research ranking.

Recreational; RO. Possibly ORV use, but this probably should be discouraged for ecological reasons, if not geological.

Industrial; I2; Low potential. Minor gravel pit operations occur. Area is within the Imperial Valley PGRA. 
Map 2

45. Mecca Hills. PC; Pliocene; ?Irvingtonian. QP; Plio-Pleistocene; ?Irvingtoniarı and Rancholabrean.

The Mecca Hills form a spectacular folded and faulted sequence of late Cenozoic nonmarine and marine sediments that unconformably rest on pre-Tertiary basement rocks. The sedimentary succession is basically the same as that of the Indio Hills to the northwest. The Mecca Formation is the basal unit, composed of up to $9800^{\prime}$ of reddish arkose, conglomerate, and claystone. This is followed upward by about $4800^{\prime}$ of the Palm Spring Formation, probably of Irvingtonian age, and $5000^{\prime}$ of Canebrake Conglomerate-Ocotillo Conglomerate.

Fossils.--Information on fossils from these units is scarce. Presumably the potential and productivity here would resemble that of the Indio Hills; that Irvingtonian fossils could be expected in the Mecca and Palm Spring Formations, those of Rancholabrean age in the Canebrake and Ocotillo conglomerates.

Reference.--Salton Sea and Santa Ana Sheets; P-104, P-106; T-14.

Institution with major collection.-- Natural History Museum, Los Angeles Values.--Research; R2. This evaluation is based on the fact that from personal observation, fossils seem to be sparse here. The stratigraphic framework is relatively well developed, however, and fossils would aid in studies concerned with the historical development of the area, and the offset of parts of it by branches of the San Andreas fault zone that pass through it.

Educational; E2. Same as above. Even without the aid of fossils, however, the geology is spectacularly exposed in Painted Canyon, and can be appreciated by itself, and in relation to the deformation along the San Andreas fault. Bedrock geology is also if interest relative to offset history of the fault. 
Map 2

45. Mecca Hills cont'd.

Recreational; RO. There is a campground in Painted Canyon, and ORV use appears mainiy limited to the canyon bottom where it can do relatively little harm.

Industrial; 12. Low potential, probabiy, but area is within the Imperial Valley PGRa. 
$\operatorname{Map} 2$

46. San Felipe Hills. PC; Pliocene; ?Irvingtonian. Tl; Tertiary; ?Irvingtonian and Rancholabrean.

This area contains some of the same units as are found in the Mecca Hills and Indio Hills, or lateral equivalents. The sediments are best exposed in the San Felipe Hills which is an anticlinorium that trends generally east-west, but has several subsidiary folds that trend southeast and northeast, as well as north.

The base of the section is comprised of the Split Mountain Formation that crops out in the southwestern Imperial Valley, near Split Mountain Gorge and Coyote Wells. It consists of a basal red and gray granitic fanglomerate, followed by medium-grained marine sandstone, and gypsum about 2,700' thick. These rocks are overlain by the marine Imperial Formation which reaches a thickness of about 3300'. The Canebrake Conglomerate: up to $6000^{\prime}$ thick, is the western, coarse-marginal, facies of the Imperial and Palm Spring Formations. The Palm Spring Formation, the main fossil-bearing unit to the south, overlies the Imperial Formation, and consists of about 6000' of interbedded siltstone, claystone, arkosic sandstone, pebble conglomerate and fresh-water limestone. The Palm Spring is the basin facies of the Canebrake Conglomerate (in part) and the marginal facies of the lacustrine Borrego Formation. The Borrego consists of up to 5000' of light brown to grayish sandstone, siltstone, and mudstone, with local units of conglomerate. The Ocotillo conglomerate (western marginal facies) and the Brawley Formation (eastern basinal lacustrine facies) occur above the Borrego, and reach a thickness of about $2000^{\prime}$.

Fossils.-- Fewvertebrate fossils have been reported from the San Felipe Hills area, but because of the proximity to the Anza-Borrego area to the south and to the Mecca-Indio Hills area to the north, which are richly to sparsely 
Map 2

46. San Felipe Hills cont'd

fossil-producing, the San Felipe Rocks have been recorded a value of high importance.

Reference.--Salton Sea and Santa Ana Sheets; P-104; T-49, T-50.

Institution with major collection.--Natural History Museum, Los Angeles

Values.--Research; R2. See above. / fossils found yet, but possibility considered good for finding more.

Educational; E2. See above. Useful for stratigraphic exercises.

Recreational; RO. Low potential; locally interesting scenery.

Industrial; $\mathbb{R}$. High potential, in general. Optical grade

calcite occurs in the Canebrake Conglomerate at the southeastern tip of the Santa Rosa Mountains. Area is within the Imperial Valley PGRA. 
Map 2

47. Anza-Borrego Area. MC; Miocene. ?Blancan. PC; Pliocene; Irvingtonian. The Anza-Borrego area lies mainly within the California State Park of the same name, and provides a canyoniand of spectacularly arrayed, folded and faulted late Cenozoic sediments. The succession is basically that described for the San Felipe Hills (no. 46). [Includes YUHA BASIN to southeast]

The main vertebrate producing units are the upper part of the Imperial Formation and the overlying Palm Spring Formation.

Fossils.--Sparse remains of ?Plesippus or Pliohippus in the upper part of the Imperial Formation suggest a Blancan age for these rocks. Late Blancan taxa in the Palm Spring Formation include Anzanycteris anzensis, Sorex, Notiosorex, Megalonyx, Hypolagus, Nekrolagus, Sylvilagus, Geomys, Perognathus, Prodipodomys, Peromyscus, Reithrodontomys, Sigmodon, Nel sonia?, Synaotomys anzensis, Coendu stirtoni, Bassariscus, Canis, Tremarctos, ?Taxidea, ?Procycil, ?Mustela, Equus, Platygonus, Titanotylopus, Hemiauchenia, Camelops, Tetrameryx, Capromeryx: Odocoileus, Euceratherium.

Irvingtonian taxa are Sorex, Notiosorex, Scapanus, Megalonyx, Paramylodon, Northrotherium, Sylvilagus, Lepus, Geomys garbani i, Thomomys, Perognatuhus, Prodipodomys, Dipodomys, Peromyscus, Onychomys, ?Baiomys, Bensonomys,

Reithrodontomys, Sigmodon, Neotomya, Microtus californicus, Coendu, ?Bassariscus, Urocyon, Canis, Smilodon cf. gracilis, Tremarctos, Spilogale, Stegomastodon, Platygonus, Equus, Titanotylopus, Hemiauchenia, Camelops, Tetrameryx, Capromeryx, Odocoileus, Euceratherium.

Reference.--San Diego-El Centro Sheet; P-8, P-89, P-11, P-12, P-21, $P-44, P-63, P-64, P-73, P-104 ; T-42, T-51$.

Institution with major collection.--Natural History Museum, Los Angeles; Imperial Valley College Museum, El Centro. 
$\operatorname{Map} 2$

47. Anza-Borrego Area, cont'd.

Values.--Research; RI. This area produces one of the best Blancan to Irvingtonian small mammal assemblages in California, and is of tremendous research value.

Educational; El. See above, for students and professionals. Recreational; RI. This is a popular tourist, ORV, camper region.

Industrial; Il. High potential. The northern part of the area is mined for gypsum. Borates are reported in Halfhill Dry Lake, and other dry lakes, but not mined. The area also is partly contained in the Imperial Valley PGRA. 
$\operatorname{Map} 2$

48. Orocopia Mountains. OC; 01 igocene; Arikareean.

The rugged Orocopia Mountains east of the Mecca Hills contain a folded and faulted sequence of Eocene marine strata and 01 igocene continental beds. The Eocene rocks, the Maniobra Formation, are about 4800' thick, and include brown shale, sandstone, conglomerate and sedimentary breccia that lies unconformably on granitic basement rock. The rocks were deposited along an ancient shoreline, or steep, near shore, buttress relationship, preserved along the southern base of the Hayfield Mountains to the northeast.

The 01 igocene rocks, the Diligencia Formation, consist of about $5000^{\prime}$ of nonmarine conglomerate, sandstone, mudstone, and interbedded flows and sills of volcanic rock, that unconformably overlie the Maniobra Formation.

Fossils.--Sparse remains of an oreodont, Merychyus cf. calaminthus have been found in the vicinity of Canyon Spring, and are the only known vertebrate fossils from this area. Personal observation, however, indicates that the rocks are potentially fossil-bearing and all should receive high priority.

Reference.--Salton Sea Sheet; P-70, P-87, P-106, P-107, P-108, P-109, P-110, P-111, P-112, P-113, P-114, T-51, T-52.

Institution with major collection.--Natural History Museum, Los Angeles. Values.--Research; R2. Mainly because of sparse remains yet found. Additional work, which is needed, could turn up more material. It is very important in that these rocks have been correlated with others in the Soledad Basin, thought to have been offset along the San Andreas fault.

Educational; E2. Possibly changing to El, see above. Recreational; RO. Relatively low; some ORV activity, and rock

hounds.

Industrial; 12. Low potential. Abandoned shafts and prospects occur, but no work is being done now. 
Map 2

49. Superstition Hilis. Qc; Quaternary; Irvingtonian and Rancholabrean

These hills, aligned northwest-southeas near the southwest tip of the Salton Sea, contain more of the sediments found in the Anza-Borrego sequence to the west.

Fossils.--Sparse fossils of Irvingtonian and Rancholabrean age are known to occur here and could be developed into a succession similar to that of Anaa-Borrego (no. 47).

Reference.--Salton Sea and San Diego-El Centro Sheets; references of the Natural History Museum, Los Angeles, no. 6733.

Institution with major collection.-- See Reference.

Values.-- Research, R2. Based on sparse nature of fossils at present. Value could change with additional collecting!.

Educationa1, E2. See Above

Recreational, RO. Probable ORV activity.

Industrial, II. Low potential. 
D. Areas in the CDCA where fossil vertebrates might occur.

As discussed in section $C$, these are areas shown in brown and yellow on Maps 1 and 2. The brown areas are considered to be of reasonably good potential for containing fossils, based largely on proximity to, or similarity in rock type to, those areas in which fossils are known or predicted to occur. The yellow areas are of lower potential, again based on experience with similar litholcgies, geologic settings, etc.

Values.--Research. The research potential of all brown or yellow areas is low, as presently known. Any of these areas can charige in potential should fossils be found subsequently. None are known to occur there now.

Educational. Similarly, the educational potential for brown or yeliow areas is low; the ranking could change once fossils were found.

Recreational. The threat of normal recreational activities to potential fossil values in these areas cannot be systematically evaluated because of the uncertainty as to the actual fossil content. It is not really meaningful to make a detailed assessment at this time.

Industrial. The same applies here. Again, most of the standard kind of industrial use of the CDCA is known, and maps of geothermal area are already at hand within the BLM. For the future, particular attention . should be paid to sitings of such featurs as geothermal wells, exploration pits, installation of new power lines, access roads to various facilities, etc. Where such developments are anticipated, an appropriate authority, such as those individuals listed in Section $H$, should be consulted as to the need for prior surveyfor fossil material. 
E. CLASSIFICATION FOR ALL SITES IN B AND C AS TO VALUE FOR: RESEARCH, EDUCATION, RECREATION, INDUSTRIAL POTENTIAL.

This information has been provided in Sections $B$ and $C$. 


\section{$F-1$}

F. IMPACTS RESULTING FROM NATURAL AND/OR HUMAN ACTIVITIES ON FOSSIL VERTEBRATE SITES IN THE CDCA.

As pointed out in Section $J$, the long-term effect of both natural and human activities on fossil vertebrate sites is to destroy them. The only realistic way to "preserve" or "conserve" fossils is to see that they are collected by someone with the necessary professional expertise, and to store them in an appropriate repository, such as a museum or educational institution. A list of such is found in Section $G$.

There are some short-term beneficial effects of natural and human activities; that is exposing the fossils to view. In the first case, that of natural activities, the erosion process will eventually destroy the fossi?, unless someone with the proper interest and/or knowledge happens to find the specimen and either removes it himself, in the manner specified above, or brings the information to the attention of someone who can. A more detailed treatment of the methods by which fossils can be collected is presented in Section $J$.

When incidental human activity, digging, trenching, and the 1ike uncovers a fossil specimen, it may be immediately destroyed unless the person involved happens to notice the specimen and knows what to do about it. The best situation, of course, occurs when the fossil is found by someone who is actively prospecting for specimens and is properly supplied to collect it.

In summary, the overall impact of natural and human activities on fossils is negative; destructive. Natural activities go on all the time; the only way to ameliorate their effect is to encourage prospecting and salvage of fossils by qualified persons. The best way to ameliorate the negative effects of other human activities is to discourage capricious use of the land in districts of high fossil potential (Section C) and to encourage surveys in such areas 


\section{$F-2$}

prior to beginning predictable activities, trenching, bulldozing, etc. Probably the single most capricious use of land in the CDCA is motorcycle extravaganzas and other kinds of concentrated ORV activity. These activities are only destructive, not just of areas with potential for fossil vertebrates, but areas with interest from a variety of biological and ecological points of view.

As a general statement, potential industrial impacts can be arranged by rock type, as follows. Almost all of these rock types occur in the majority of the areas numbered in Section C, and colored blue on Maps 1 and 2, as well. as areas colored brown, and to a somewhat lesser extent in areas colored yellow.

Fluviatile Deposits.

Sand and gravel operations

Resistate minerals; mining

Manganese deposits

Volcanic, pyroclastic, and tuffaceous deposits

Silica mining

Scouring agents

Zeolites

Roofing rock

Pumice mining

Perlite mining

Cinder mining

Lightweight aggregates

Clay minerals

Lacustrine deposits

Lightweight aggregates

Tufa and building stone

Gypsum mining

Strontium mining

Borate mining

Halite mining

Magnesite mining

Barite mining

Clay and bentonite

Lead-silver-zinc deposits

Semiprecious stones and commercial lapidary deposits 
Other industrial developments might occur

Transmission corridors

Access roads

Sites for generating stations, microwave relay stations, etc.

Resort and recreational development, and ancillary impacts to public land

(e.g., Lewis Development proposed for 4 th of July Canyon, New York Mountains.)

\section{Mitigation of Impacts}

Most industrial and commercial projects of any magnitude will come to light in the process of obtaining procedural permits. These include mining claim applications, grading plans, reclamation plans, and a variety of environmental assessments. Projects might ränge from surface disturbances to extensive excavation, any of which might have adverse impacts upon significant paleontologic values.

Mitigation is straightforward and generally does not require undue delay of any project. It consists first of a paleontologic survey prior to construction and, secondly, of having a monitor present during all phases of construction to watch for paleontologic values which might be enccuntered. In both cases, the survey and monitoring must be done by a trained paleontologist who is equipped to salvage fossils rapidly to avoid costly delays.

Successful paleontologic monitoring has taken place at such major excavations as railroad realignments and freeway construction. Depending on the extent of the fossiliferous deposits, one to four trained paleontologic observers and a crew chief were employed. They closely followed graders, scrapers, and dozers for periods of up to eight weeks. Removal of significant paleontologic values took place with minor rerouting of equipment and no loss of construction time.

When budgeting for a paleontologic salvage, funds should be included for preparation and curation of specimens as well as for equipment and salaries during construction activities. 
Informal, nonstructured activities which are not controlled by procedural permits will be the most difficult to monitor. Activities such as prospecting and exploratory mine work, rockhounding, and vehicle related activities may introduce individuals or small groups into areas where they will deliberately or inadvertently damage paleontologic values. Loss of scientific knowledge from these activities and from erosional forces can best be prevented by periodic collection of specimens from fossiliferous sediments by individuals and groups from accredited institutions. Definitions

"Significant paleontologic values" are those which are unique, unusual, rare, uncommon, or diagnostically important. Generally, these would include the fossil remains of large, small and microscopic vertebrate animals, rare or uncommon invertebrates, and fossils of animals and plants previously unrepresented in a certain portion of a stratigraphy.

Fossil specimens are different than other ecologic values in that they are confined to certain sedimentary deposits, but most often occur randomly throughout such a deposit. Consequently, to locate and preserve (remove) paleontologic values, mitigating measures are necessary in areas of paleontologi - vàlues identified by literature search or previous field experience. 
Specific Localities where known industrial potentials might create impacts to signilicant vertebrate fossil localities:

Valley Wells T.16N R.12E

1. Mining prospects indicate interest in tufa which caps fossiliferous sediments. Increased need for lightweight aggregate might revitalize prospecting and mining.

2. The Valley Vells Copper Smelter and the Evening Star Mill might be revitalized as milling sites, as bases for commercial operations. The dumps and stockpiles might be reworked.

3. Valley Wells is traversed by above-ground and subsurface utility corridors. Expansion or addition to these routes might impact significant fossils. Expansion will need to be monitored by a paleontologic obeerver.

4. The Beck Spring Iron Mines on Kingston Peak, when active, heavily impacted the fossiliferous sediments with vater storage ponds, gravel pits, staging areas, and roads. This occurred despite complaints to the BLil by the San Bernaroino County Museum. Renewed usages would cause further impacts.

5. Recreationalists and local residents familiar with the Barstow-Vegas 500 vehicle race continue to use the fossiliferous badlands for O.R.V. practice.

\section{Piute Valley Sediments T.13N R.19E}

1. By prospecting and some mining, tufa and tufaceous sediments were shipped, probably for use as lightweight aggregates. Claim markers are as recent as 1974. Changes in ecomonic trends might stimulate interest in these deposits.

2. Utility corridors through Piute Valley might be expanded . A paleontologic obeerver should be present in that eventuality.

3. Cattle watering lines through the fossiliferous sediments might be retrenched and impact significant vertebrate fossils.

\section{Shadow Mountains Sediments T.17N R.9, $10 \mathrm{E}$}

1. Prospects for clay are common in fossiliferous sediments. These showed activity in 1975.

2. Red Canyon gypsum deposits appear to have had recent visitations.

3. Claim markers appear along the contact of thrust piates of paleozoic rocks and tertiary sediments. 


$$
\mathbf{F}-6
$$

(localities - 2)

Yucca Grove Tufaceous Sediments T.15N R.IIE

1. This lacustrine section is near proposed CalTrans rest stop. A shift in plans might impact these sediments.

2. Subsurface gaslines have impacted these sediments. Further expansion will necessitate the presence of a paleontologic observer.

Aztec Sandstone "T.15 1/2 N R.14 E, T.16N R.13E.

1. Jurassic sandstone has been quarried in the past and might be developed as a quarry in the future.

2. Recent claim markers indicate prospecting in this formation for the "Lost River of the Golden Sands". Dinosaur trackways might be impacted if heavy equipment is used.

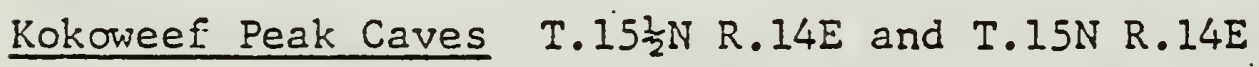

1. Extensive prospecting has impacted fossiliferous fill of Kokoweef, Crystal, and Quien Sabe caves. Further removal of fossiliferous pleistocene fill should be monitored by a paleontologic obeerver.

2. Spelunkers might remove fossils from caves in the Mescal Range and at Kokoweef Cave.

Pinto liountain T.13N R.15E

1. Interest has been expressed in prospecting for zeolites in this area.

Hole-in-the Wall Tuffaceous Sediments T.IIN R.15E

1. Extensive prospecting for lapidary materials continues to impact potentially fossiliferous sediments.

2. Interest has been expressed in prospecting for zeolites in this area.

Old Dad Dune Sands T.11N R.10E

1. Utility corridors are present and might be expanded. If so, a paleontologic observer should be present to monitor fossiliferous sediments. 
Wild Horse Mesa T.11N. R.14E

1. Prospecting of tuffaceous sediments has impacted fossiliferous sediments.

2. Interest has been expressed in prospecting for zeolites in this area.

3. Collection of lapidary material from fossiliferous sediments might impact or cause removal of fossils.

\section{Barber Opal Beds T.11N R.14E}

1. Collection of lapidary material has included removal of petrified wood and might impact vertebrate fossils.

2. Interest has been expressed in prospecting for zeolites in this area.

(April, 1978)

3. A drilling program is prospecting for molybdenite (?) in the same section (16). where the fossilifercus seciments occur. west of

Beecher Canyon T.11N R.14E.

1. Interest has been expressed in prospecting for zeolites in this area.

Domingo Spring, Whiskey Spring T.IIN R.14E

1. Spring development for ranching might further impact fossiliferous sediments.

Cave Spring T.11N R.15E

1. Spring development for ranching might further impact fossilifcrous sediments.

2. Prospecting, road work, and recent claim markers (1975) are located west of Cave Spring. Workings were apparently for turquoise and might be revitalized.

Juan, Castle Mountains T.15N R.18E

1. Perlite mining, clay mining, and prospecting for zeolites might impact fossiliferous sediments. 
(localities - 4)

2.: This area is subject to rockhounds looking for petrified wood. Such use might impact vertebrate fossils.

Grandview Sediments T.12N R.18E

1. Prospect pits exist from sampling caliche, which caps potentially fossiliferous sediments.

Hackberry Mountains T.11-12 N, R.17E

1. Extensive mining and collection of chalcedony for lapidary material has directly impacted significant vertebrate fossils. This area continues to attract large groups of rockhounds.

2. Yucca harvesting in this area will create vehicle tracks which might increase O.R.V. use, thereby impacting fossiliferous sediments. in this area.

3. Interest has been expressed in prospecting for zeolites

Vontrigger Hills T.11-12N R.17E

1. Yucca harvesting in this area will create vehicle tracks which might increase O.R.V. use, thereby impacting fossiliferous sediments.

2. Interest has been expressed in prospecting for zeolites in this area.

Big Tiash Sandstone T.6N R.18E

1. Claim markers appear in the vicinity of potentially fossiliferous sediments. Development would require a paleontologic observer.

Sands Lacustrine Sediments.

1. Additional utility corridors might impact significant vertebrate fossils.

Salt Basin T.18N R.5E

1. Recent claim markers and prospects suggest interest in clay or saline minerals. 
(localities - 5)

Bitter Spring T.13N R.5E

1. Tenneco Cil Co. undettook a drilling program for borates in Tertiary sediments during 1977.

Alvord Sediments T.12N R.4E

1. Prospecting by a Mr. Sparks occurred in and near fossiliferous sediments during 1977.

Haddin Ranch Sediments T.7N R.2E

1. Current cattle ranching operations might impact potentially fossiliferous sediments.

Gravel Pits - Twentynine Palms T.1N R.9i

1. Gravel operations continue to impact fossiliferous sediments east of 29 Palms.

Cinnamon Roll Sediments T.6N R.2E

1. Pleistocene sediments in BLM's "O.R.V. Open Area" are continually impacted by recreaticnalists.

Wild Road Sediments T8N R.4W

1. Pleistocene sediments near Wild Road offramp are continually impacted by recreationalists in O.R.V.s.

Calico Hills - Tin Can Alley T.ION R, 2E

1. Exploratory drilling programs for borate minerals starting in 1977 might impact significant fossils.

Owl Canyon Camp, Barstow Fossil Beds T.11N R.2W

1. Visitors of B.L.M. campgroung in Owl Canyon often bring fossils to BLM personnel. Unreported removal of paleontologic values probably occurs regularly. 


$$
F-11
$$

(localities - 6)

Kramer Hills T.9N R.6W

1. A drilling program to explore Tertiary sediments for radioactive materials took place in approximately 1974. 


\section{$\underline{S} \underline{I} \underline{G} \underline{N} \underline{C} \underline{A} \underline{N} \quad \underline{C} \underline{0} \underline{L} \underline{L} \underline{E} \underline{C} I \underline{I} \underline{0} \underline{N}$}

American Museum of Natural History

Dr. R.H. Tedford

Dept. of Vertebrate Paleontology

AMNH

79th Street at Central Park West

New York NY 10024

Los Angeles County Museum

Dr. D.P. Whistler

LACM

900 Exposition Blvd.

Los Angeles CA 90007

San Bernardino County Museum

Robert E. Reynolds

220 S. Buena Vista :

Redlands CA 92373

University of California - Berkeley

Dr. D.E. Savage

Museum of Paleontology.

U.C.B.

Berkeley CA 94720

University of California - Riverside

Dr. M.0. Wcodburne

Dept. of Earth Sciences

U.C.R.

Riverside CA 92521

Webb School (Raymond Alf Museum)

$\mathrm{Dr}$. Raymond M. Alf

1175 W. Baseline

Claremont CA 91711

Imperial Valley College Museum

Dr. George G. Miller

El Centro CA 


\section{$\underline{S} \underline{P} \underline{E} \underline{C} I A L \underline{I} \underline{S} I \underline{S} \quad \underline{W} I I \underline{H} \quad \underline{I} \underline{N} I \underline{E} \underline{E} \underline{S} I$}

Akersten, William A.

Los Angeles County Museum of Natural History

900 Exposition Blyd.

Los Angeles CA 90007

Alf, Raymond $M$ :

$1175 \%$. Baseline

Claremont CA 91711

Clemens, William A.

Dept. of Paleontology

U.C. at Berkeley

Berkeley CA 94720

Dailey, W.R.

Dept. of Earth Sciences

U.C. at Riverside

Riverside CA 92521

Golz, David

Geological Museum

$U$. of Hyoming

Laramie WY 82070

Howard, Hildegard Mrs.

2045 Q Via Mariposa East

Laguna Hills CA 92653

Hutchison, John $H$.

Museum of Paleontology

U.C. at Berkeley

Berkeley CA 94720

Jefferson, George $T$.

Page Museum

La Brea Tar Pits

Los Angeles CA 90007.

Meyer, Grant E

Raymond Alf Museum

$1175 \mathrm{~W}$. Baseline

Claremont CA 91711

Miller, George G. Dr.

Imperial Valley College Museum

El Centro CA

Repenning, Charles

U.S.G.S. Paleontology and Stratigraphy Branch 345 Middlefield Road

Men To Park CA 94025 
Reynolds, Robert E.

220 S. Buena Vista

Redlands CA 92373

Savage, Donald

Museum of Paleontology

U.C. Berkeley

Berkeley CA 94720

Whistler, David P.

Los Angeles County Museum

900 Exposition Blvd.

Los Angeles CA 90007

Woodburne, Michael 0.

Dept. of Earth Sciences

U.C. at Riverside

Riverside CA 92521 
I. CROSS-INDEX FOR MAPS, TEXT, INSTITUTIONS WITH COLLECTIONS AND BIBLIOGRAPHY.

This information is provided in section $C$. 
3. VALUE, OCCURRENCE, RECOVERY, PRESERVATION AND COLLECTION OF VERTEBRATE FOSSILS 1-A. VALUE, SCIENTIFIC

Vertebrate fossils are of great potential scientific value. The word potential is used here because some parts of the skeleton are of greater immediate scientific value than others, at least in the terms of identifying the genus and species that the animal represents. Identification is the first aim of the scientist, because all subsequent studies are based on that information. Depending on the kind of animal represented, certain parts of the skeleton are more important for this purpose than others, and only a competent paleontologist is qualified to make that initial appraisal in the field (See Section 5). Even though teeth or parts of the skull and jaws that bear them are usually considered more important than other parts of the skeleton, and have the additional value in being composed of some of the hardest and thus most preservable skeletal tissues, increasingly modern refinements in taxonomic studies (identification and evolutionary relationships) require that more information be obtained. For example, in order to make a reputable generic and specific identification of a fossil camel it is necessary to have at hand much of the skull, jaws, and their teeth, and front and hind metapodials (elongate "cannon" bones between the wrist and ankle bones, respectively, and the toes). For most horses, one needs the teeth in the jaws and skull and at least part of the snout between the orbits and the nasal region.

Once identification has been acheived, the paleontologist can make assessments as to the age of the rocks in which the fossils occur, and begin to interpret the geologic, environmental, and paleoecologic setting in which the animals lived and. died.

Other kinds of studies are just as important as the above, however, and require knowledge of increasingly greater parts of the skeleton. For example, studies of functional morphology, in which the interrelationships of the parts 
of the skeleton are studied, can lead to important interpretations as to the way the animal moved, how it ran, climbed, or flew, etc., what was its gait. These studies are not only important for themselves, in showing how the locomotion of modern animals was evolved, but also give information that can feed back directly into considerations of the environmental and paleoecologic setting, mentioned above. Additionally, the style of preservation of postcranial parts of the skeleton bears importantly on studies in taphonomy how and under what conditions did these fossils accumulate at this particular site - which again feeds back into environmental and paleoecologic setting. Post-cranial parts of the skeleton can also yield important information as to the age - in terms of life span - of the fossil animal. This information contributes to studies on the age-structure of the fossil population. Are primarily young individuals being preserved here, or is there a relatively even distribution of age classes? These considerations are important to studies in taphonomy, mentioned above.

The point being made here, with only a few examples, and an incomplete iist of possible kinds of study, is that ultimately all parts of the skeleton are of about equal importance for science. The scientific value of fossil vertebrates is not translatable into dollar terms, and of course the rare specimens that are sufficiently complete to be amenable to display in public museums and the like are of inestimable human, instructional, as well as scientific value. Every fossil vertebrate has some value. Those with the lowest scientific value, but not necessarily zero, are those specimens that can be shown to be non-identifiable. This decision can only be made, of course, by a qualified specialist.

Recommendation -.--Finds of fossil vertebrates should be immediately broughtto the attention of a paleontologist at one of the institutions listed in Section $H$ of this report, for evaluation as to the next steps to be taken. 
1-B. VALUES, COMMERCIAL

Even though fossil vertebrates are of so inigh a scientific value as to be valueless in dollar terms, dollar figures are given to fossils for various reasons.

One of the more common of these is the situation where an individual donates a collection of fossils to an institution, and would like a statement as to value for purposes of Income Tax deductions. In these cases, the scientist usually estimates what it would have cost him, as a professional, to go out and collect those fossils (mileage and time), and the subsequent cost, if any, of cleaning, preparation, and curation, depending upon the state of the collection being donated. Similar kinds of considerations (essentially the cost of replacing the fossil, if it could be replaced) are made when dollar values are assigned to fossils when being insured for purposes of mailing, inventory, etc. .

Another consideration is the rarity (usually related, but not always, to the completeness of preservation and representation of all parts of the skeleton) of the specimen. There are very few "rules of thumb" to follow here. One might try to calculate how many man-hours would need to be spent in search of such a specimen (this would vary tremendously - fossil fishes are more commonly found as more or less complete skeletons than any other kind of vertebrate), as well as to prepare and mount it for display.

Inevitably, a few private individuals will collect fossil vertebrates for the purpose of sale to the general public or to scientific institutions. Occasionally, such institutions have purchased important collections, but the dollar figure is usually only to recompense the individual for his outof-pocket expenses. Sale of fossil vertebrates to the general public is clearly done for profit, and this should be discouraged at every opportunity. In cases where it can be shown that the fossils were collected from lands falling under 
the jurisdiction of federal or state antiquities acts, such sales are clearly illegal.

Recommendations -.-- Except for tax related purposes, or those of assigning values for insurance, inventory, recompense for out-of-porket expenses for private individuals selling collections to scientific institutions, giving dollar values to fossil vertebrates should be discouraged. The only way to ensure that fossil vertebrates can be brought into the collections of scientific institutions, and can be made available to the general public in a reputable way, and thus enhance knowledge and education, is to discourage private collectors from selling fossils for profit to the general public. This is not necessarily a mundane issue. A year or so ago. Time Magazine reported that pre 5 tigeous New York shops made a practise of selling publicly various kinds of fossils, including vertebrates, for their "artistic" or "conversationpiece" value. The prices ranged into the thousands of dollars. The only logical way for such fossils to have been supplied to these stores is by private collectors. 


\section{OCCURRENCE}

Except for being found primarily in sedimentäry rocks, fossil vertebrates are very unpredictable as to occurrence. Some kinds of fossils are more closely restricted than others. For example, fossil fishes are normally encountered in ancient lake beds, or along with other marine vertebrates in near-shore marine deposits. Land living, tree-climbing, burrowing, or flying vertebrates are more commonly encountered in terrestrial fluviatile (stream) or near-shore lacustrine (lake) deposits. Some have been encountered in sediments during the drilling of wells, and, in at least one insţance, a fossil rhinoceros was entombed in a lava flow in Oregon. Deposits of asphalt and peat make excellent places to search for fossils, because of the nature of the materials being formed. Fossil vertebrates have also been found in ancient artesian springs, and in ancient dune sands.

Essentially, to preserve a fossil, it must be covered up, and rapidly enough after death so that the skeletal parts are not destroyed by animal and environmental agencies. Any covering or enclosing agent whether water- or airborrie sediment, air fall tuff, asphalt, etc., is capable of preserving a fossil. Certain post-depositional effects can destroy once preserved fossils, however, and these include sediments that have been subjected to extensive weathering and leaching of material, or those subjected to very acidic percolating solutions, such as in some swamps and bogs. Other post-depositional effects, such as extreme burial and metamorphism will destroy most fossil vertebrates.

Some post-depositional effects are beneficial. Unless there is great vertical relief, the potential for finding fossils is usually greater if the sediments have been tilted to some degree because this exposes a greater thickness than otherwise would occur at the land surface, and the pattern of streams and tributaries, provides a better three or four sided exposure of the rocks than normally would occur in most flat-lying terrains. 
But the above are only peripheral to the main problem. Fossil vertebrates are selectively involved in the transportation and burial process. A very small proportion of the vertebrates that die, do so in a place that is amenable to their preservation. Both in the water and on land, activities of scavengers, bacteria, and various natural weathering or decompositional agencies will cause carcasses to break up and disintegrate into more or less unrecognizable pieces before they can be preserved. The factors that affect this process of disintegration or removal are so variable as to prevent accurate prediction of where a fossil vertebrate will occur. Any paleontologist can cite numerous examples in which two sedimentary layers occur in the same locality and are of so great lithologic similarity as to be indistinguishable from each other on a lithologic basis. Yet only one will contain fossils. Sediments deposited in ponds, lakes, marine lagoons, or at mouths of rivers or streams entering those areas, and sediments deposited on river flood plains or alluvial fans have the greatest potential for yielding fossil vertebrates. Not all sediments in the above categories will yield fossils, however, and identifying those particular kinds of sediments in contrast to those deposited in other environments requires geological interpretations that are not always possible. Generally, but not always, finer-grained sediments have a higher potential in this regard than do coarser-grained sediments. Asphaltic or peat deposits are rel- i atively rare generally, and are certainly so in the CDCA.

Recommendations-.--For the above reasons, the management of fossil vertebrates in the CDCA should assume until contradicted by hard evidence (i.e. a thorough investigation has been conducted) that nearly all sedimentary rocks in the CDCA have the potential of yielding fossil vertebrates. No area in which sedimentary rocks occur should be "written off" without thorough tests. The only possible exception might be areas where the ground is completely covered by very recent alluvium. 


\section{RECOVERY}

This section will discuss how fossils are found, as distinct from collecting them. Fossils are found, briefly, by walking over the area in question and searching for them visually. Fossils commonly display shapes and textures that are distinct from those of other particles in sedimentary rocks, and just what those differences are is only gained by experience. other tools, of use to other areas of earth sciences, such as aerial photographs, remote sensing devices, or even driving along an area in some form of motor transport, are not sufficient means with which to search for fossils. Inspection must be done on foot, at close distances. It should be stressed here that searcining for fossils is a distinctly different procedure from making a geologic study of the area. The paleontologist covers the ground in much greater detail, sometimes on hards and knees, and is looking for distinctly different things, and normally in different parts of the same area or outcrop than is the geologist. People making geological studies cio find fossils, of course, but almost never to the same degree or volume as the paleontologist. It is entirely possible and conceivable that a geologist could make a very good, detailed study of an area and find no fossils at all. This should not be taken as an indication that fossils do not occur in the area. In cases too numerous to mention individually, a paleontologist will inspect an area along with or after a geologist and find many fossils that were completely overlooked by the other person.

Similarly, an anthropologist will inspect an area in different places and for different reasons than will a paleontologist. By their very nature, artifacts of man are normally set down, or developed, on something, which could easily be granitic or a volcanic rock, where a paleontologist would never expect to find fossils. Even when anthropological remains are developed on sedimentary rocks, such locations will normally be reasonably flat. An anthropologist 
normally does not expect to find artifacts along the sides of reasonably steep slopes or in the sides of cliffs. Such sites could easily yield fossil vertebrates because they are contained within, rather than on, the rocks. For somewhat different reasons than in the case of the geologist, an anthropological survey of an area can easily overiook sites that contain fossil vertebrates. Again, an anthropological survey cannot substitute for a paleontological survey for a reliable estimate of the presence or absence of fossil vertebrates. Recommendations-.--Whenever evidence is needed as to the presence or absence of fossil vertebrates, a paleontological survey should be conducted. Siatements in anthropological or geological technical reports or published Titerature that "no fossils were found" shouid not be taken as evidence that fossils are, in fact, absent. 


\section{PRESERVATION}

This section deals with a brief paragraph on the natural preservation of fossils, and then turns to another side of preservation, that of making fossils available for study and education.

In the natural state, fossil vertebrates are preserved by various minerals that are brought to the bones after burial by percolating ground water. The range of natural preservation varies greatly, from essentially completely replaced bone ( $i t$ is now something else, for example, $\mathrm{SiO}_{2}$ ), or almost no replacement at all, and variations in between.

No matter how well preserved, however, fossils cannot long exist at the surface of the earth, and begin to degrade and fracture almost immediately upon being exposed to natural agencies. For this reason, the collector normal$7 y$ adds various preservatives in the collecting process, and this will be discussed in the following section on collection. The inability of fossil vertebrates to long withstand the attack of natural agencies at the surface of the earth is a critical part of the discussion of how best to preserve fossils for study and education.

There is only one answer. Fossils must be collected by competent scientists and brought to the laboratory of the institution for additional preparation, hardening, cleaning, under controlled conditions, and then curated into the collections or displays of that institution. Only then will there be a long term, reliable, resting place for the fossils, that is available to repeated use by scientist, student, or member of the general public. The scientist is the only reputable custodian for these specimens. Only he has the necessary interest, expertise, and through his institution, necessary level of funding to ensure that these invaluable specimens are well and consistently taken care of, utilized and made available for the benefit of all.

There is only one exception, which works well in one instance and poorly 
in others. This is preserving the fossil in place in the rock in the field. The best example is Dinosaur National Monument where the Department of the Interior has built a permanent structure over the area where the fossils are being excavated, and provided funds for continuing excavations and supervision of this very valuable teaching as well as scientific resource. The reason this facility succeeds is that funding is available for continuous operation and supervision, and public access and activity can be controlled. Except that the building is constructed over the rock itself, and the fossils not totally housed in museum cabinets or in halls on display, this situation is directly comparable to the institution/scientist housed and cared for fossils mentioned above.

More 1 imited approaches to preserving fossils in their natural state exist, and those I have seen do not succeed. The approach has been to build small, box-like, covers of plexiglas or similar material over the fossils, which had been cleaned and exposed prior to being covered. These fossils occur along trails, and are available to view by the public without supervision. Informative plaques are also constructed alongside the fossils, explaining their significance. The problem comes from lack of continual supervision. Many of the plaques refer to fossils that are no longer under their protective structures. They have been destroyed or removed by the public they were meant to serve. If the person who stole the fossil still has it, it is serving the interest of one, or at best very few people. When interest lags or stops, the fossil will be at best relegated to an attic, and eventually destroyed. In contrast to a scientific instititution, where one specimen can potentially serve thousands of people over many generations, the stolen specimens will serve one or two, for a generation or less. Without adequate continuous interest, funding, and supervision, it is just not possible to make a valid case in favor of "preserving the fossils in their natural state.". 
Recommendations-.--Long-term preservation of fossit vertebrates, in service to generations of scientists and members of the general public, can only be achieved under the auspices of recognized governmental (federal, state, municipal) agencies or comparable even though privately funded museums that can provide the necessary interest, supervision and funding. 


\section{COLLECTION}

The skills and tools needed for the collection of vertebrate fossils depend mainly on the size of the fossil and the kind of sediment in which it occurs. Fossils are most commonly found by noticing scraps of bone or teeth that have heen washed down the surface of a slope or cliff. It is best to try to collect everything that can be found, so the usual procedure is to begin at the base of the slope or cliff and slowly work upward, picking up everything. These pieces can normally be placed in a soft cloth or paper bag. When the actual specimen is finally reached, the next stage in the decision-making process begins, basically what approach to use and what tools will be required. Tools-.--Depending on the requirements of the situation, the collector will select from the following 1ist. Large or small pick axe, shovel, rock saw, jack hammer, pin vise with needles, dental scrapers, awls, assorted chisels, siedge hammer (both one and two handed), assorted soft brushes, whisk broom, bathroom tissue, newspaper, masking or gum tape, plastic basin for mixing plaster, plaster-of-paris, burlap bags or sheets, scissors, linoleum knives, timber, nails, hammer, rope and wire, assorted paper bags, pry bars.

Exposure and hardening-.--The first step is to determine, if possible, what part of the skeleton is represented, whether it is largely on the surface, or whether it extends into the sediment; if the latter, how much overburden is likely to be above the bone (if the specimen is exposed in a sheer cliff face, 10 's of feet of overburden may be present, but even this can be sometimes removed from above with pry bars or - only for the initiated - dynamite).

If the specimen is small and largely exposed at the surface, it is usually a relatively simple matter to carefully brush off or pry off with small tools the little sediment remaining, and apply a hardening solution. If the specimen is larger, the situation becomes more complex, as discussed below. Application of a hardening solution is almost always necessary, even for the best preserved 
specimens, because bone exposed to the surface is normally slivered or fractured to some extent. Hardening solutions are diverse, but a common type is Glyptal Lacquer Cement, No. 1276 and Lacquer Thinner No. 1511-M, made by General Electric. In the uncut state the cement is a perfectly good glue; thinned at a ratio of about $1: 6$, the solution will penetrate the pores in the fossils and sediment, and upon drying (30 minutes or longer depending on the temperature) will hold the pieces together well enough to withstand careful handling and packing. Other solutions include Duco Cement thinned in Acetone, Elmer's (or any white) Glue, thinned with water, or Shellac thinned with alcohol. The last combination is rarely used any longer, because the shellac is very difficult to remove when the fossil is being re-cleaned and put together in the laboratory.

Normaliy, only the exposed surfaces are hardened. Unless the fossil is - very small, or dense, or both, it usually cannot be picked up in its entirety and wrapped. Larger, and particularly longer, specimens are normally collected with some of the enclosing sediment attached. The hardening process requires a variable amount of time depending on the nature of preservation, porosity or friablility (crumbly-ness) of the sediment, etc. Decision as to when the specimen has been hardened enough requires a certain amount of experience.

Removing the specimen from the sediment-.--The case of small, dense specimen has been discussed above. For larger specimens, it is not alvays necessary to expose all of the bone. In fact, it is usually better to disturb the fossil as little as possible. Clean and harden what was originally exposed, and remove enough superficial sediment to determine the size of the element, the direction it is projecting into the rock, and whether or not it is attached to, or associated with, other elements. Estimating this possiblity requires considerable knowledge of skeletal anatomy. Once this has been determined, an excavation is begun, at a distance of from $2-6$ " or even more, from the bone 
depending on its size, the hardness of the enclosing sediment, and the extent to which it is fractured. This excavation is designed to isolate the specimen, with its surrounding sediment, from the rest of the outcrop, and may need to be dug to a depth of a few inches to a foot or more, again depending on the size and shape of the bone, its preservation, the rigidity of the sediment, fracturing, etc., and this, again, requires professional experience and judgement.

In a simple case, it may be sufficient to isolate the specimen on a small pedestal, and assuming here that the sediment is coherent, it may be possible to cut through the base of the pedestal with the same small tools (awls, linoleum knives) used to excavate the pedestal in the first place. The specimen then can be wrapped and labelled (discussed below).

In more complex cases, because the rock is friable, or the specimenis large, it is not sufficient to only make a pedestal, even if it is a foot or more tall. It is necessary to make a plaster jacket to hold everything together. First one must protect the fossil from the plaster, because it will be very difficult to separate the two afterward. Separation is usually achieved by tightly packing (by means of strippling action with a soft brush dipped in water) several layers of bathroom tissue. An eighth to a quarter of an inch of tissue is usually sufficient, but occassionally greater thicknesses may be required. The strippling action tightly packs the material around the nooks and crannies of the bone, and if some of these are very deep, additional packing is added to give the overall surface a reasonably smooth outline, aga in to facilitate separation of the fossil from the plaster jacket in the laboratory.

The pedestal must be undercut to some extent, usually prior to the tissue packing process, so that the base is narrower than the top. When these two operations are completed, strips of burlap are cut, in widths of $3-6^{\prime \prime}$, depending on size of the fossil and degree of surface irregularity (thin strips 
can be fitted into nooks and crannies of the pedestal more easily than wide ones). These must be long enough to reach from the base of the pedestal on one side, up and over the specimen, and down to the base of the pedestal on the other. Enough strips must be cut so that they can overlap each other from side to side by about $20-30 \%$. An extra long strip must be cut to completely encircle the base of the pedestal, to anchor all of the other strips. If the specimen is reasonably small (a foot or so in length, or less), it is usually sufficient to have only a single series of strips. If the specimen is larger, a number of crisscrossing layers must be used.

When the number, size, and direction of strips has been determined, a11 must be immersed in water, the excess being wrung out. Additional water is added to the plastic basin to a level determined largely by experience, and plaster-of-paris slowly added. The attempt is to provide a mixture with the consistency of thick cream; if too thin, the plaster will be too weak, too tinick, and it will not penetrate the burlap and will not set properly.

The strips of burlap are immersed one by one in the plaster, sone of the excess wrung out, and then laid over the fossil and pedestal. Each strip is applied to the pedestal with a careful strippling motion of the fingers, so that it tightly fits not only over the fossil but also in all nooks and crannies of the pedestal. This ensures a tight fit when the jacket dries, so that the pedestal and fossil will not rattle around, and break, in the jacket when dry.

After all the strips have been placed over the pedestal, and strippled into place, the basal collar is wrapped around the base of the pedestal so that all the strips will be firmly attached. The specimen is now allowed to dry, but before completely dry, the field number (discussed more fully below) can be drawn in the soft plaster with a pointed tool.

After the plaster is completely dry and hard, the base of the pedestal 
can be cut through, below the basal collar, using whatever tools are proper to the nature of the job. The aim is to enable the collector to turn the pedestal over, ultimately upside down, without any of the enclosed sediment falling out. This is why the pedestal is under cut, to make the base narrower than the top.

Depending on how large the pedestal is, and how heavy, some of the interior sediment can be removed so that there will not be too much weight on the fossil (which is now on the bottom). It may be necessary to cut off, with linoleum knives, some of the plaster jacket to remove this sediment. If the fossil is to be transported to the laboratory in the field vehicle, it may not need additional treatment. If the sediment is very soft, or if the fossil is to be transported in a crate by truck or rail, it will be necessàry to make a burlap strip and plaster cap for the exposed base.

Additional support may be required for specimens that are either very large or long (long dimension greater than two to four feet depending on the situation). These can consist of any strong object, branches of trees or bushes, lumber, iron 'pipe, etc., and are applied at the time the original jacket is made, being incorporated into the burlap strip network. Sometimes these supports are added so that the specimen can be conveniently carried by two or more people, or if very. large, fork lift, hoist, etc.

Wrapping and labelling-.--Jacketed specimens, as described above, will contain their field number etched into the jacket. It can also be written on with marking pen. Smaller specimens must be carefully wrapped in layers of bathroom tissue and, depending on size, either secured with masking or gum tape, or wrapped further in newspaper, and then secured. A field number is written on each package. The date and general location are also usually added on the package as well as in the field notebook.

The labelling of specimens with a consistently applied numbering system 
is essential. If the specimen comes from an already known and numbered locality, the locality number should also be written in the notebook and on the package and jacket. It doesn't matter what kind of numbering system is used as long as it is consistent. One format is to use the initials of the collector, a year code, and a specimen code. In my case, Mow 7801 would be the first field number I used in 1978. The second would be MOW 7802 , etc. Every specimen gets a separate field number, unless it can be proved that the bones all came from the same individual animal. Then all get the same field number. This is critical. A consistent field numbering system is the only way to accurately tie the specimen to its location in the sedimentary sequence. Only in this way will it be possible to accurateIy record the relative stratigraphic positions of the various fossils collected in a district. The progressive evolutionary development of vertebrates can be documented only if very careful field records are kept so that it can be determined that Specimen A came from a certain number of feet, meters, or inches above or below another.

Locality records-.-- The location of the sites from which fossil vertebrates are recovered must be carefulty recorded, for the same reasons as the field number must be recorded. Initialiy, the locality number may be derived from the field number of the first specimen collected from that site, aithough more than one specimen can come from one site. In the above example, Mow 7801 would refer to the first specimen to come from a given locality, and the locality would also be known initially by that number. MOW 7802 could be the second specimen to come from the same locality as $1.10 \mathrm{~W} 7801$, and would be so noted in the field notebook. In the laboratory, a master set of locality numbers. is kept, and at UCR these are noted: RV-7801, etc. R=UC Riverside; $V=$ vertebrate fossil; 7801 means the first locality recorded in 1978. MOW 7801 and MOW 7802, etc. would be various specimens collected 
from RV-7801. MOW 7801 and HOW 7802, etc., also could pertain to a locality. originally collected earlier, such as RV -7605 , so the system is flexible. The "formal" RV- locality number is applied when that locality is first written up in the master locality files in the laboratory.

In the field, the field number that applies to the locality must be written in the field notebook with an accompanying description of the geology, stratigraphy, location, etc. This field number must also be plotted on a.15' or $7.5^{\prime}$ topographic map. It is best if the locality is also plotted on an aerial photograph. Scales of topographic maps are standardized, however the possible range of scales for aerial photographs is greater. The scale pertinent to the study being undertaken depends on the nature of the project and the spacing of information desired.

Localities plotted in the field can then be given "formal" field localities when these are written up for the master files in the institution. Notes and records made in the field should be as complete as possible. Attempts should be made to tie all localities studied on each excursion into a physical stratigraphic framework, even if distances and thicknesses are approximate. This can be refined, if necessary, during later visits, but no fossil should be removed from an area without sufficient information having been obtained to accurately show its location, stratigraphic position to the rock sequence and to other fossils.

When to designate a new locality-.--This is a matter of some experience. If specimens are found only a few feet, or even a few 10's of feet, apart it may not be necessary to designate more than one locality. This is particularly true if the specimens come from the same bed. Similarly, specimens coming from within a few inches or feet of one another in a vertical, stratigraphic, sense, may be given a single locality number, but it is still best to record the vertical or lateral distance in the field notebook. 
If specimens occur at greater distunces, howcver, it is lisually best to designate new locality numbers, at least in the field. In the laboratory, it may turn out that the specimens are of closely the same age even though separated by some lateral 0 . stratigraphic distance, so that only one formal RV- locality is designated. In the field, however, it is always better to be conservative. When in doubt, award a new field number locality.

Laboratory preparations-.--Once the fossils are brought to the laboratory, they must be unwrapped, placed in trays with cards showing at least the appropriate field number, and readied for further cleaning and preparation. This work usually continues the use of hardners, solvents, small picks and brushes. In the case of plaster jackets, however, the plaster and burlap layers must be cut off, beginning at the base and working toward the fossil, and sediment encouritered during this process removed. Ultimately, the underside of the fossil is reached, can be treated delicately, additionally hard'ened, and finally' removed.

Curation-.--After the specimens are cleaned and hardened, they must be supplied with a formal Locality and Specimen number. The field number that applies to the original locality number (assuming it is new for this excursion) will be assigned to whatever formal locality number is appropriate, and that locality description written up in the formal locality card file. Anything else pertinent to tying that locality to field records will be noted on the formal locality card file, including pertinent topographic map, aerial photograph, field notebook, name of the collector.

The specimen number and locality number are written on the specimen in ink, or if it is too small, on the cork of the glass vial in which it sits. All specimens are also provided with specimen cards, that lie in the same tray that contains the specimen. This card shows the taxonomic identification, the formal specimen number, the kind of element represented, the formal locality 
number, the name of the rock unit in which the specimen was found, name of the fauna (see below), a general geographic notation, and the name of the collector and the person making the identification. The original field number also should be recorded on the locality card. Thus, the fossil is completely crossreferenced to field notebook, its place in the collection, and its location in the formal specimen and locality catalogues.

Faunal names-.--Fossil vertebrates are representatives of once-living animal populations, which can be called faunas, or local faunas. It is common practise to refer to fossil samples from one or more localities, showing the same assemblage of anaimals as a fauna. Thus, fossils of similar taxonomic character from rocks in the Northern Cady Mountains are known as members of the Cady Mountains Local Fauna. The rocks from which the fossils come are known as the Hector Formation, and the use of different names prevents confusion between discussions of the rocks or the animals.

It is possible to arrange fossil vertebrate collections in the laboratory either by their evolutionary, faunal sense or by their taxonomic identity. At UCR, we use the faunal arrangement, so the faunal name on the specimen card shows where the specimen is to be found in the collections. In the taxonomic scheme, animals of the same family or genus would be put in the same part of the collection, no matter where they came from, so it is difficult to easily find out what was the faunal representation at a given locality without an additional set of references.

A defect of the faunal method of arrangement is that it is difficult to easily find out what is available as to the skeleton of a given animal, not from just one locality, but all the localities in the collection. This requires another set of references, which has not been initiated at ICR as yet. At present, a manual search is usually sufficient. 
Map 2

40. Sands. Qc, Qs; Quaternary; Rancholabrean.

There are a series of sites near the ATSF Railroad tracks and the highway, along the southwestern edge of the Devil's Playground, ahout one mile northwest of Sands Junction (on the railroad line). The fossils occur in brown and dark grayish-green fine-grained lacustrine sandstone, and stiltstone, overlain by a cap of tufa.

Fossils.--Equus, Camelops, Mammuthus, ?Hemiauchenia, and associated lacustrine gastropods.

References.--Kingman Sheet; locality records of San Bernardino County Museum (1-62-1 and 2) and Department of Earth Sciences, University of California, Riverside (RV-7001 to 3$)$; $P-23$.

Institution with major collection.--San Bernardino County Museum; Department of Earth Sciences, University of California, Riverside.

Values.--Research; R1. Important Rancholabrean locality, with bearing on age of lacustrine deposition in Mojave Desert.

Educational; E1. See above; students and professionals.

Recreationa $1 ;$ RO. Low potential possibly ORV activity along railroad tracks.

Industrial; I2: Low potential. 


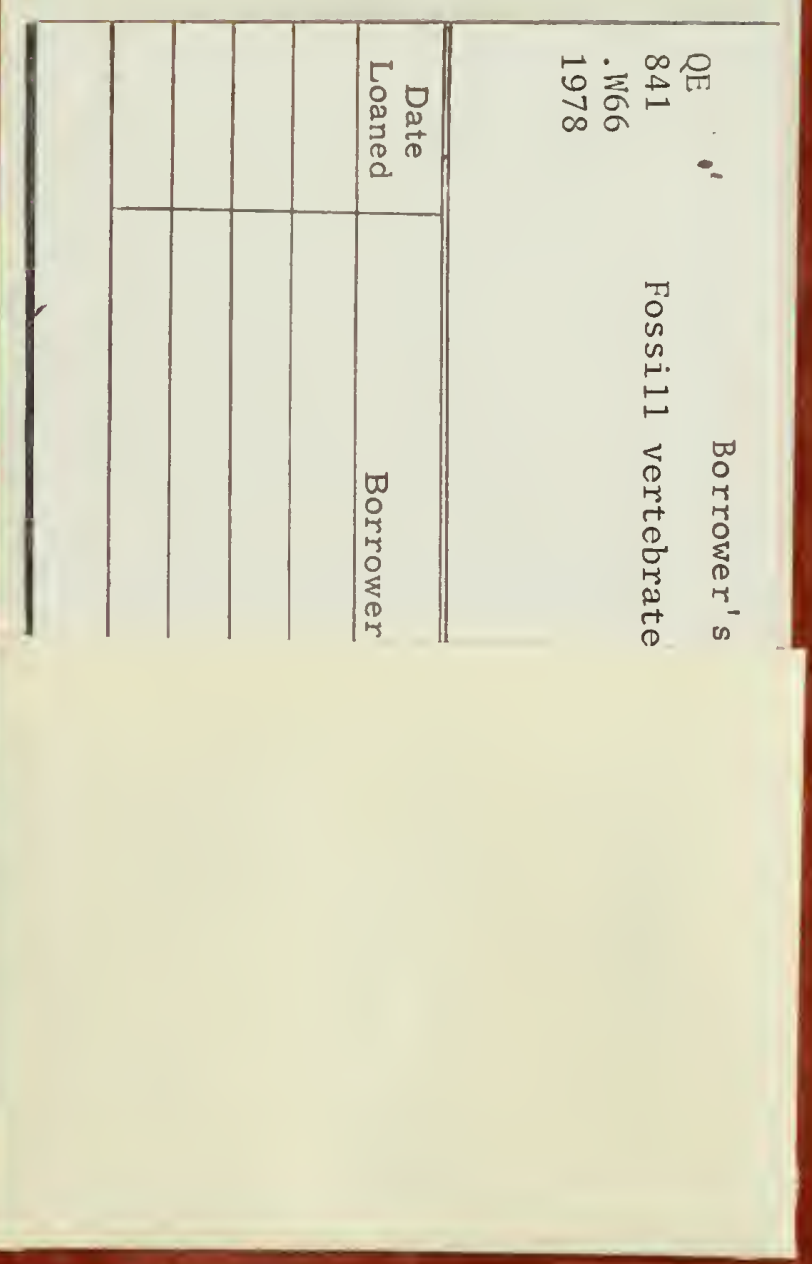


